\title{
New marine gastropod records for the Hellenic waters
}

\author{
Thanasis Manousis ${ }^{1 \dagger}$, Constantinos Kontadakis ${ }^{2 \dagger}$, Georgios Polyzoulis ${ }^{3 \dagger}$, George Mbazios ${ }^{4 \dagger}$ \\ and Sofia Galinou-Mitsoudi ${ }^{{ }^{*}+}$ (B)
}

\begin{abstract}
Background: The Hellenic Seas are influenced by on-going environmental changes and the introduction of alien species, which are expected to have an impact on their biodiversity. This study contributes to the knowledge of the Hellenic marine gastropod biodiversity, expanding data over the entire Greek territory, during the period from October 2008 to March 2017.

Results: This work presents 45 species of gastropods not previously reported from Greece or reported only once, belonging to 19 families. From those species, one (Horologica sp.) is, most probably, an undescribed species, 17 are new for the Eastern Mediterranean Sea and 40 are new for the Hellenic fauna. Main taxonomic characteristics and ecological information such as habitat, distribution and origin, are given and discussed.
\end{abstract}

Conclusions: By this report, the Hellenic gastropod biodiversity is enriched by 40 new records, out of which, 17 are new for the Eastern Mediterranean Sea, 4 are Lessepsian migrants previously reported for the Mediterranean Sea and 1 is probably a new species.

Keywords: Biodiversity, Gastropods, Mediterranean Sea, Greece

\section{Background}

The Mediterranean Sea is rich in biodiversity. Almost two decades ago, about 8500 species have been estimated to occur [1]; this number doubled recently to more than 17,000 species [2]. This impressive increase is attributed to (a) the rising number of relevant studies in new areas and at different depths and biotopes, (b) the introduction of alien species, which reached almost 1000 species by 2012 [2], and (c) the increasing rate of modification of the Mediterranean Sea ecosystems [3]. The environmental changes that have influenced the biodiversity during the last three decades, the reasons for the occurrence of aliens, the frequency of the records, the vectors and the

*Correspondence: galimits@otenet.gr

†Thanasis Manousis, Constantinos Kontadakis, Georgios Polyzoulis,

George Mbazios and Sofia Galinou-Mitsoudi contributed equally to this work

${ }^{5}$ Department of Civil Engineering, School of Technological Applications, Alexander Technological Educational Institute of Thessaloniki (A.T.E.I.Th.), PO Box 141, 57400 Thessaloniki, Greece

Full list of author information is available at the end of the article distribution pathways have been extensively discussed [2, 4-12].

The Hellenic Seas, as a part of the Eastern Mediterranean Sea, have been influenced by the on-going environmental changes, and Aegean Sea, in particular, after a long and slow cooling period from the late sixties to the early nineties, started to warm rapidly [13]. As a result, dense waters from the Adriatic Sea shifted to the Aegean Sea, a phenomenon known as the "Eastern Mediterranean Transient" [14, 15]. These environmental changes combined with the effects of navigation and sea currents, were expected to have an impact on the biodiversity. Indeed, recent publications revealed new species for the Hellenic Seas [16-22]. The aim of this study was to further contribute to the knowledge of the Gastropod fauna of the Hellenic Seas.

\section{Results}

The records

Among the 226 specimens collected, 45 species were identified belonging to 19 families and are listed with 
data on their habitat, mode of life and origin in Table 1. Among them, 4 are recognized as already known for the Mediterranean Sea Lessepsian migrants, 17 as new for the Eastern Mediterranean Sea fauna, and 40 as new for the Hellenic fauna (collection stations are indicated in the map of Fig. 1 while the species are presented in Figs. 2, 3, $4,5,6,7,8,9,10,11,12,13,14,15,16,17,18,19,20,21$ ).

\section{The documented records for the Hellenic Seas}

All 1st and 2nd documented records from the Hellenic Seas are presented bellow per family; a brief description is given whenever additional information is supportive to their identification.

\section{Fissurellidae Fleming, 1822}

Diodora funiculata (Reeve, 1850) (Fig. 2a). Three live individuals (20.00-29.00 $\mathrm{mm}$ long, 13.45-20.00 $\mathrm{mm}$ wide, $8.65-13.00 \mathrm{~mm}$ high) from mixed bottoms, -1 to - $2 \mathrm{~m}$, station 14. A Lessepsian migrant reported from the coast of Israel and established there [23]. It is uncommon in the Egyptian Red Sea [24] while the species is distributed in the Arabian Gulf [25].

Fissurisepta granulosa Jeffreys, 1883 (Fig. 2b). One shell (2.30 mm long, $1.00 \mathrm{~mm}$ wide, $1.20 \mathrm{~mm}$ high), $-400 \mathrm{~m}$, coralligenous bottom, station 1. Circalittoral of deep waters of West and Central Mediterranean; rare [26-29].

\section{Lepetidae Gray, 1850}

Iothia fulva (O. F. Müller, 1776) (Fig. 2c). Six shells (1.70$6.30 \mathrm{~mm}$ long, $1.40-5.60 \mathrm{~mm}$ wide, $1.00-4.00 \mathrm{~mm}$ high), $-400 \mathrm{~m}$, coralligenous bottom, station 1 . Fresh shells of I. fulva bear a yellow to light orange periostracum [28]. The species is distributed in the continental shelf from NE Atlantic to the Azores [27, 28, 30,31]. It is rare in the Mediterranean Sea [27] mainly found in central Tyrrhenian and Adriatic Seas [29] and occasional in SW Albania [32].

Propilidium exiguum (W. Thompson, 1844) (Fig. 2d). Seven shells (1.40-2.80 mm long, $1.20-2.30 \mathrm{~mm}$ wide, 0.90-1.60 mm high), $-400 \mathrm{~m}$, coralligenous bottom, station 1. European coastal zone to deeper than $2500 \mathrm{~m} \mathrm{[28,}$ 33-37].

\section{Anatomidae McLean, 1989}

Anatoma tenuisculpta (Seguenza, 1880) (Fig. 3a). Two shells $(0.90$ and $2.40 \mathrm{~mm}$ high, 1.20 and $3.00 \mathrm{~mm}$ wide, respectively) - $400 \mathrm{~m}$, coralligenous bottom, station 15. An uncommon species with wide depth distribution range ( 50 to $>1800 \mathrm{~m}$ ) in $\mathrm{N}$ and $\mathrm{W}$ Europe and in the Mediterranean Sea [38]; numerous shells were found in the Alboran Sea [31].

\section{Addisoniidae Dall, 1882}

Addisonia excentrica (Tiberi, 1855) (Fig. 3b). One shell (12.40 mm long, $10.35 \mathrm{~mm}$ wide, $5.60 \mathrm{~mm}$ high), $50 \mathrm{~m}$, mixed bottom, station 30. Uncommon, West Mediterranean $[35,39,40]$.

\section{Skeneidae Clark W., 1851}

Akritogyra conspicua (Monterosato, 1880) (Fig. 3c). 23 shells (1.10-1.90 mm high, $1.40-2.40 \mathrm{~mm}$ wide), - $400 \mathrm{~m}$, coralligenous bottom, station 1. Uncommon, West Mediterranean [27, 41] and East Mediterranean [42] up to the Sea of Marmara, in depths > $1000 \mathrm{~m}$ [43].

Cirsonella romettensis (Granata-Grillo, 1877) (Fig. 4a, b). Three shells (1.60-1.80 mm high, $1.60-1.80 \mathrm{~mm}$ wide), $-400 \mathrm{~m}$, coralligenous bottom, station 1 . Rather common, West Mediterranean [27, 35, 41].

Lissomphalia bithynoides (Monterosato, 1880) (Fig. 4c). One shell (0.90 mm high, $1.00 \mathrm{~mm}$ wide), mixed bottom, - $80 \mathrm{~m}$, station 27. Common, Mediterranean, of infralittoral to bathyal distribution $[27,36,41,44]$.

\section{Chilodontidae Wenz, 1938}

Danilia costellata (O.G. Costa, 1861) (Fig. 5a-c). One live specimen and 13 shells (2.65-10.00 mm high, 2.55$6.55 \mathrm{~mm}$ wide), biogenic material and maerl, 80-120 m, stations 23, 24 and 25. Protoconch paucispiral of one smooth whorl followed by half a rather smooth whorl with axial ribs. Next whorls are decorated with distinct wavy spiral cords. The body whorl bears 14-15 axial prosocline $\left(15^{\circ}-20^{\circ}\right)$ ribs crossed by spiral cords and forming shallow cavities. Columellar tooth variable from small to big in size and from pointed to square in form. 14-15 main teeth on the outer lip and several secondary. Unicolor of moccasin color in general. Very similar to $D$. tinei (Calcara, 1839) (Fig. 5d) but the latter bears 17-18 axial prosocline cords $\left(30^{\circ}-35^{\circ}\right)$ while the cavities of the decussated areas are deeper. Its outer lip bears less main teeth (10-12) and the shell is whitish with about 8 brown zigzag zones of flames (not as spots) [35]. Danilia costellata was referred from the Mediterranean Sea by Palazzi and Villari [45], Crocetta and Spanu [46] and Cossignani et al. [47] as certain, by Vilvens and Heros [48] as doubtful and Herbert [49] characterized that of Crocetta and Spanu [46] as tentative. In contrast, D. tinei was referred from the Mediterranean Sea by many more researchers including Gofas et al. [35], Ghisotti and Steinmann [50], Cachia et al. [51], Navaro and Capdevila [52], Scaperrotta et al. [53] and Öztürk et al. [54]. Based on the available bibliography, the two Mediterranean Danilia species have overlapping taxonomical characteristics including the shell outline, the ratio height/width, the shape and size of the collumellar tooth and the depth distribution range. Moreover, as the juvenile shells exhibit no 


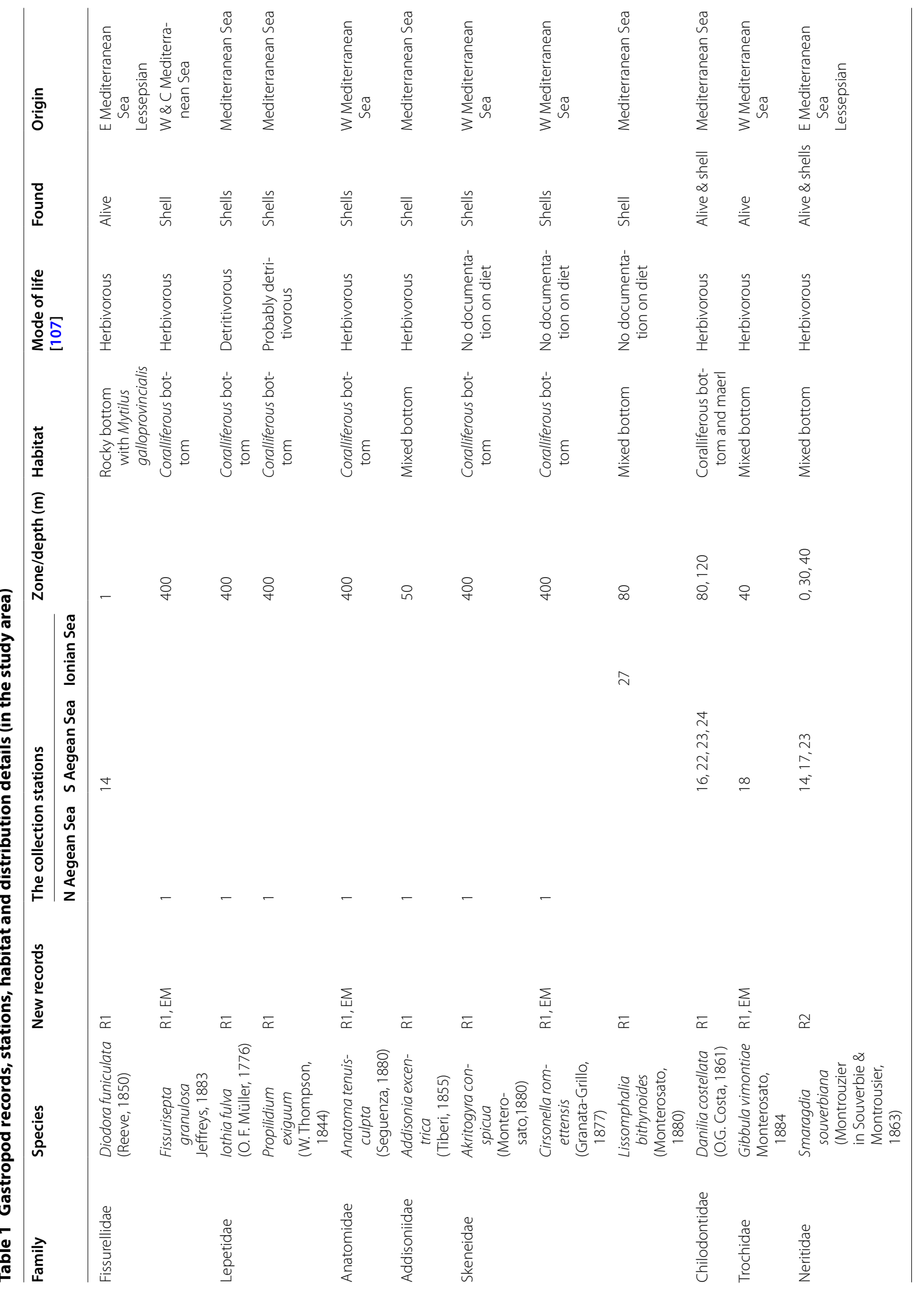




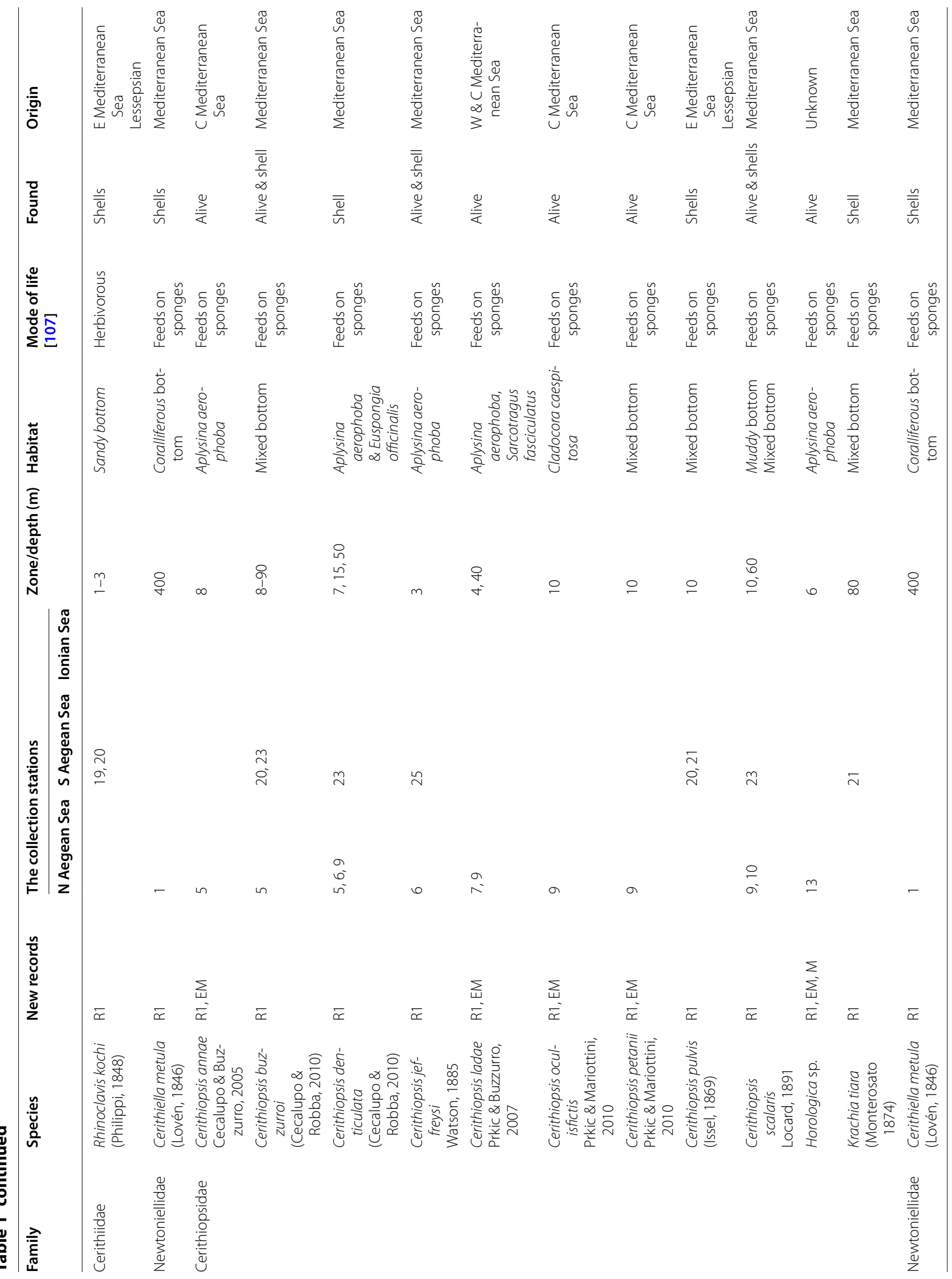




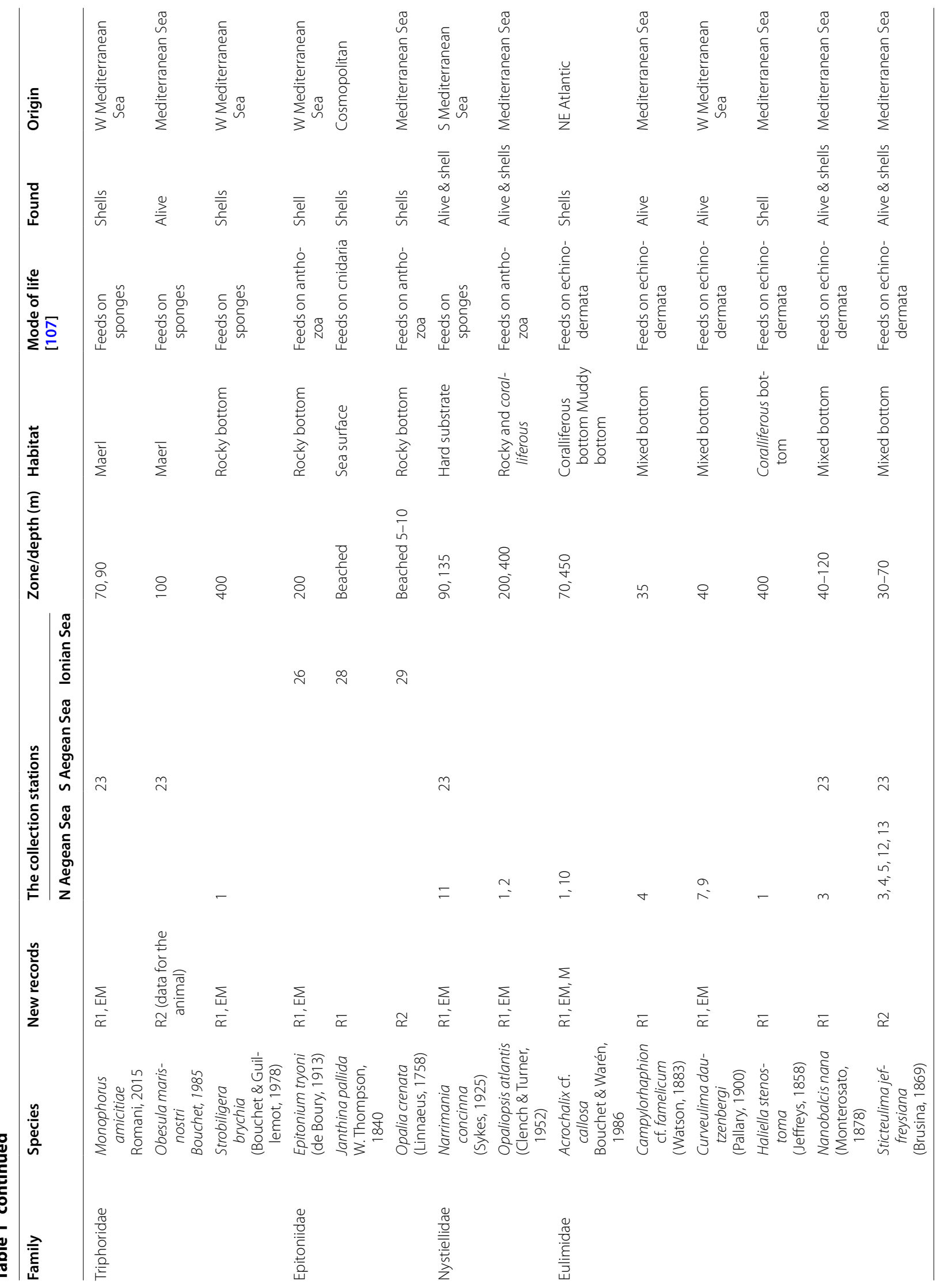




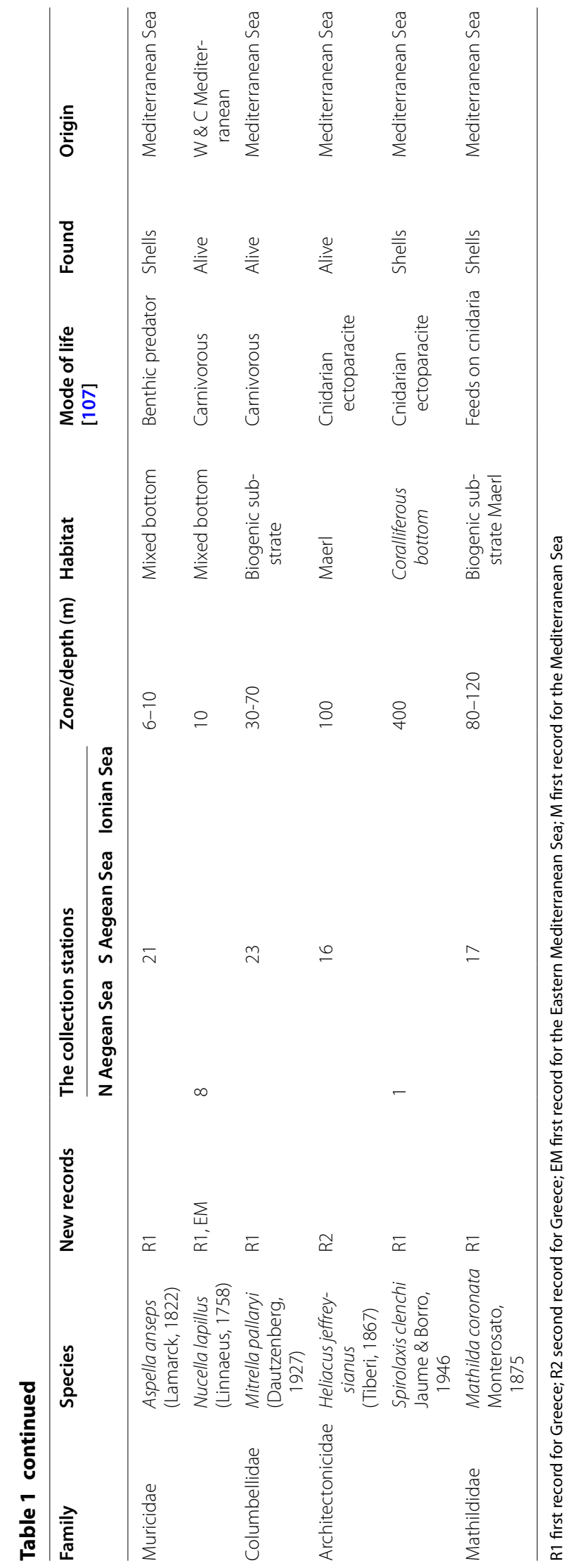




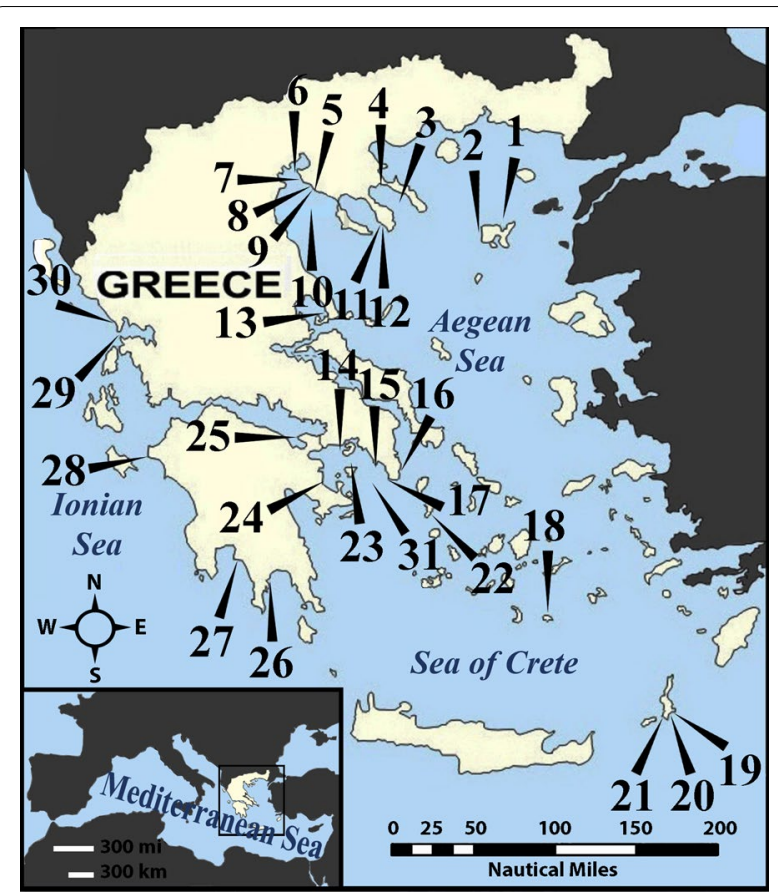

Fig. 1 Map of collection stations for the species reported in this study. Stations in North Aegean Sea: 1. Limnos Island; 2. Kaspakas, Limnos Island; 3. Central Siggitikos Gulf; 4. Pyrgadikia, Chalkidiki; 5. Cape, Epanomi; 6. Aggelohori; 7. Nea Michaniona; 8. Palioura, Epanomi; 9. Paralia, Epanomi; 10. Central Thermaikos Gulf; 11. Toroni, Chalkidiki; 12. Tristinika, Chalkidiki; 13. Chorto, Pagasitikos Gulf. Stations in South Aegean Sea: 14. Eandio, Salamina Island, 15. Anavissos, Attiki; 16. Lavrio, Attiki; 17. Legrena, Attiki; 18. Anafi, Island; 19. Damatria, Karpathos Island; 20. Diakoftis, Karpathos Island; 21. Amoopi, Karpathos Island; 22. Kythnos, Island; 23. Central Saronikos Gulf; 24. Epidaurus Gulf; 25. Ireo, Korynthiakos Gulf. Stations in the Ionian Sea: 26. Gythio, Lakonikos Gulf; 27. Kardamili, Messenian Gulf; 28. Castro, Kyllini; 29. Kanali, Preveza; 30. Pantokratoras, Preveza. 31. South Saronikos Gulf

differences [55], a further study of these two congeneric species seems to be necessary.

\section{Trochidae Rafinesque, 1815}

Gibbula cf. vimontiae Monterosato, 1884 (Fig. 6a). One live juvenile specimen ( $0.85 \mathrm{~mm}$ high, $0.95 \mathrm{~mm}$ wide), - $40 \mathrm{~m}$, mixed bottom, station 26. It is presented as $G$. cf. vimontiae due to its more globular outline and the smaller size than that presented by Scaperotta et al. [59]. Gibbula vimontiae is uncommon in the West Mediterranean [27], quite common in beached detritus in Tunisia, or Mediterranean [56, 57], North Atlantic [58] and Rhodes [59].

\section{Neritidae Rafinesque, 1815}

Smaragdia souverbiana (Montrouzier in Souverbie \& Montrousier, 1863) (Fig. 6b, c). One live individual and two shells (2.32-3.30 $\mathrm{mm}$ high, 2.50-3.35 mm wide) mixed bottom, 0-40 m, stations 14, 17 and 23. Smaragdia souverbiana is a known Lessepsian reported from Cyprus and Turkey [6] and recently from Lesvos Island, NE Aegean Sea $[60,61]$. In Australia, this species consumes various seagrass species with a strong preference for Zostera capricorni Ascherson, 1876 and Halophila ovalis (R. Brown) J.D. Hooker, 1858 [62]. The Lessepsian angiosperm Halophila stipulacea (Forsskål) Ascherson, 1867 was referred from all places where S. souverbiana was recorded, assuming that $H$. stipulacea might also be the food of S. souverbiana in the Mediterranean Sea.

\section{Cerithiidae Fleming, 1822}

Rhinoclavis kochi (Philippi, 1848) (Fig. 7a-c). 32 shells (5.30-36.50 mm high, 2.00-9.50 mm wide), sandy bottom, -1 to $-3 \mathrm{~m}$, stations 19 and 20. The species was characterized as one of the 100 "Worst Invasive" [63].

\section{Newtoniellidae Korobkov, 1955}

Cerithiella metula (Lovén, 1846) (Fig. 7d). Two shells (2.50 and $3.80 \mathrm{~mm}$ high, 0.90 and $1.40 \mathrm{~mm}$ wide, respectively), $-400 \mathrm{~m}$, coralligenous bottom, station 1 . It is mainly distributed in NE Atlantic, being extremely rare in the Mediterranean Sea [64] or rare in Central and East Mediterranean [27]. Gofas et al. [31] do not confirm the presence of the species in the Mediterranean Sea.

\section{Cerithiopsidae H. Adams \& A. Adams, 1853}

Cerithiopsis annae Cecalupo \& Buzzurro, 2005 (Fig. 8a). One live specimen ( $3.40 \mathrm{~mm}$ high, $1.35 \mathrm{~mm}$ wide), in Aplysina aerophoba (Nardo, 1833) sponge host, $-8 \mathrm{~m}$, station 6. The species is compared with C. tubercularis (Montagu, 1803), C. nana Jeffreys, 1867 and C. minima (Brusina, 1865) (see Figs. 8b, 9a, b, respectively). It is recorded in shallow waters of the West $[47,65,66]$ and Central Mediterranean Sea [57, 67].

Cerithiopsis buzzurroi (Cecalupo \& Robba, 2010) (Fig. 10a, b). Three live specimens and nine shells (2.65-4.45 mm high, 0.95-1.45 mm wide), mixed bottom, $-40 \mathrm{~m}$, station 5 ; -6 to $-8 \mathrm{~m}$, station 20 ; -50 to - $90 \mathrm{~m}$, mixed bottom, station 23. Sublittoral, Mediterranean [67].

Cerithiopsis denticulata (Cecalupo \& Robba, 2010) (Fig. 11a-d). Five shells (2.35-5.35 mm high, 0.85$1.35 \mathrm{~mm}$ wide), $-7 \mathrm{~m}$, in Aplysina aerophoba (Nardo, 1833) sponge host, station 2; - $15 \mathrm{~m}$, Spongia (Spongia) officinalis Linnaeus, 1759 sponge host, station 5; Zostera bed, $-0.2 \mathrm{~m}$, station 6 ; $-70 \mathrm{~m}$, hard substrate, small scale fishing nets, station 23. Infralittoral and upper circalittoral throughout the Mediterranean Sea [67].

Cerithiopsis jeffreysi Watson, 1885 (Fig. 11e, f). Two live specimens (1.90 and $3.10 \mathrm{~mm}$ high, 0.75 and 


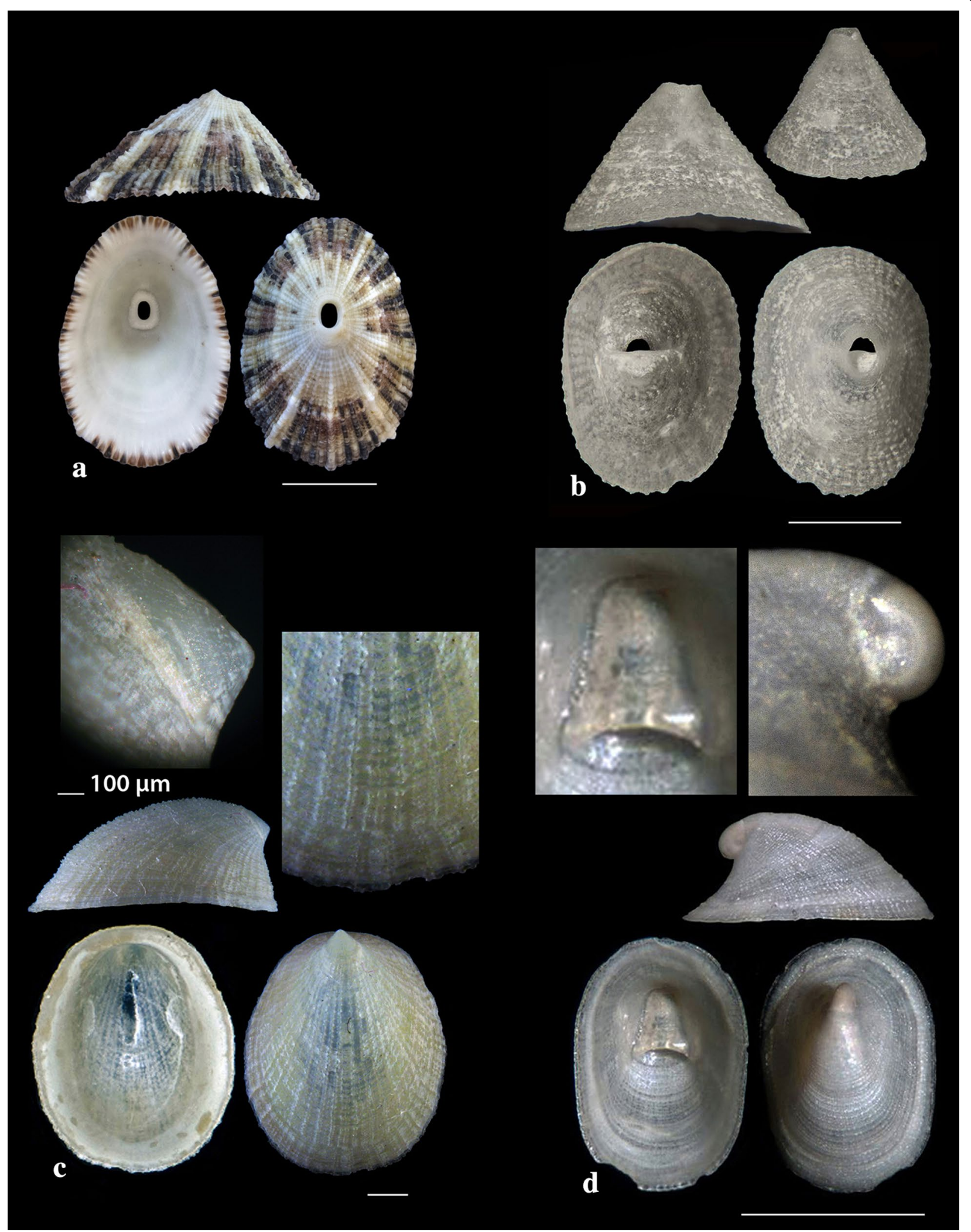

Fig. 2 a Diodora funiculata, b Fissurisepta granulosa, c lothia fulva, $\mathbf{d}$ Propilidium exiguum. Bar $=1 \mathrm{~mm}$, unless otherwise indicated 


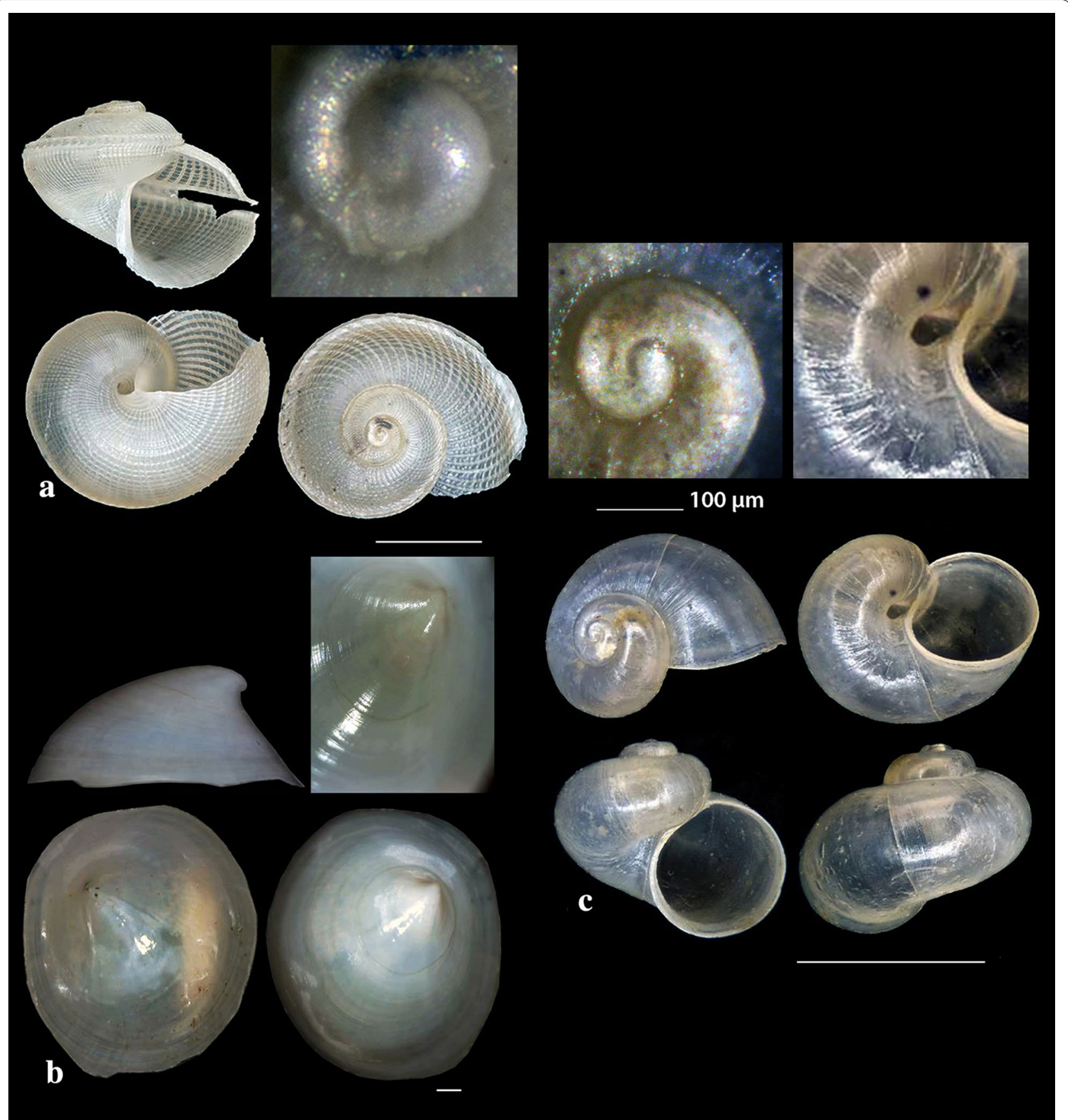

Fig. 3 a Anatoma tenuisculpta, b Addisonia excentrica, c Akritogyra conspicua. Bar $=1 \mathrm{~mm}$

$1.00 \mathrm{~mm}$ wide, respectively), -3 and $-8 \mathrm{~m}$, in Aplysina aerophoba (Nardo, 1833) sponge hosts, stations 6 and 25. Uncommon [68], Mediterranean [27, 35, 44]. It is also recorded from NE Turkish Aegean Coasts [54].

Cerithiopsis ladae Prkić \& Buzzurro, 2007 (Fig. 12a). Five live specimens and two shells (1.60-2.00 mm high, 0.75-0.90 mm wide), in Aplysina aerophoba (Nardo, 1833) sponge host, -4 and $-8 \mathrm{~m}$, stations 3 and 6;
Cladocora caespitosa (Linnaeus, 1767) scleractinian, - $40 \mathrm{~m}$, station 5. Uncommon, West and Central Mediterranean Sea [29, 35, 69-71].

Cerithiopsis oculisfictis Prkić \& Mariottini, 2010 (Fig. 12b). Two live specimens (3.80 and $4.00 \mathrm{~mm}$ high, 1.00 and $1.10 \mathrm{~mm}$ wide, respectively), $-10 \mathrm{~m}$, among Cladocora caespitosa (Linnaeus, 1767) scleractinian coral branches, station 5. Adriatic Sea [72]. 


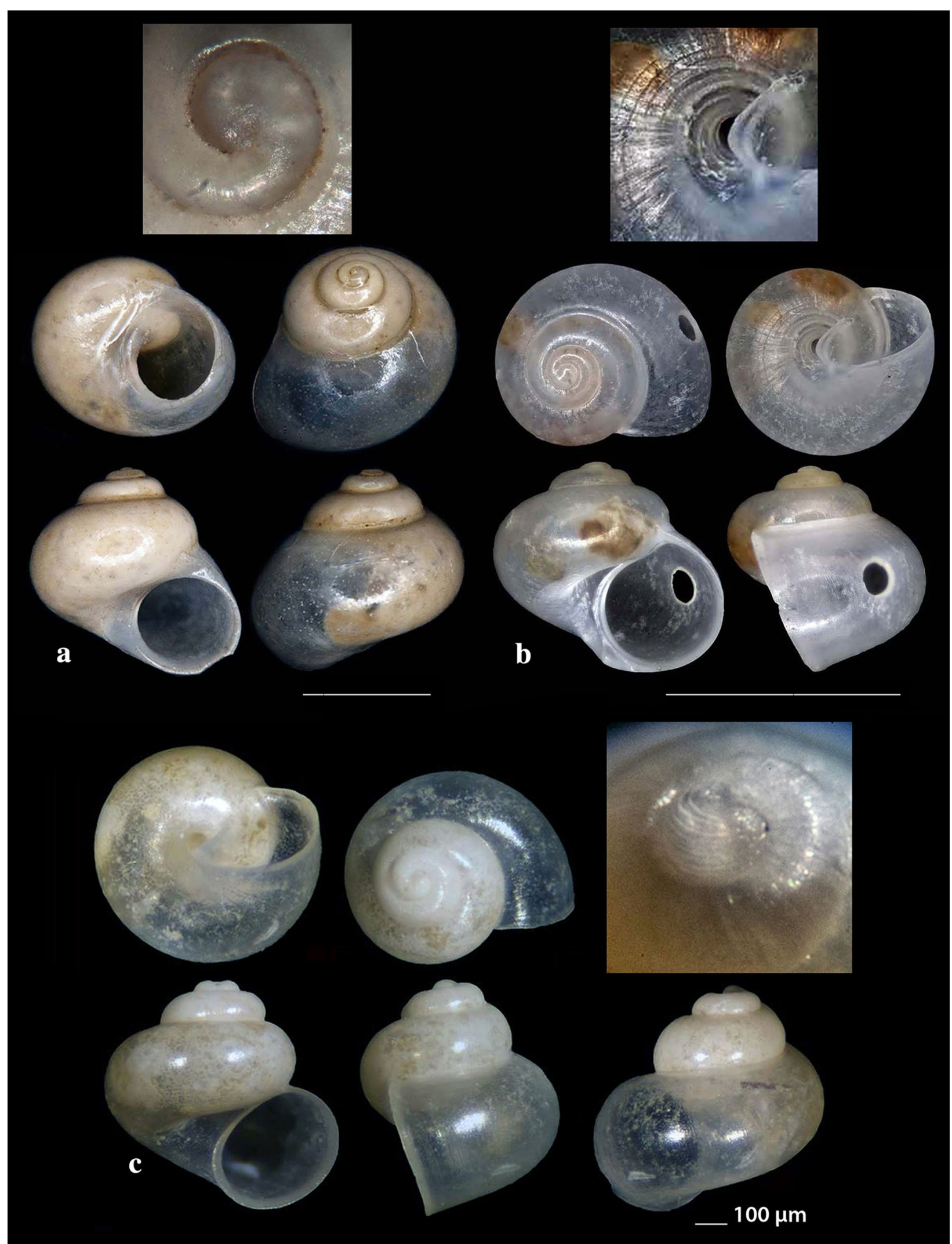

Fig. 4 a, b Cirsonella romettensis, $\mathbf{c}$ Lissomphalia bithynoides. Bar $=1 \mathrm{~mm}$, unless otherwise indicated 


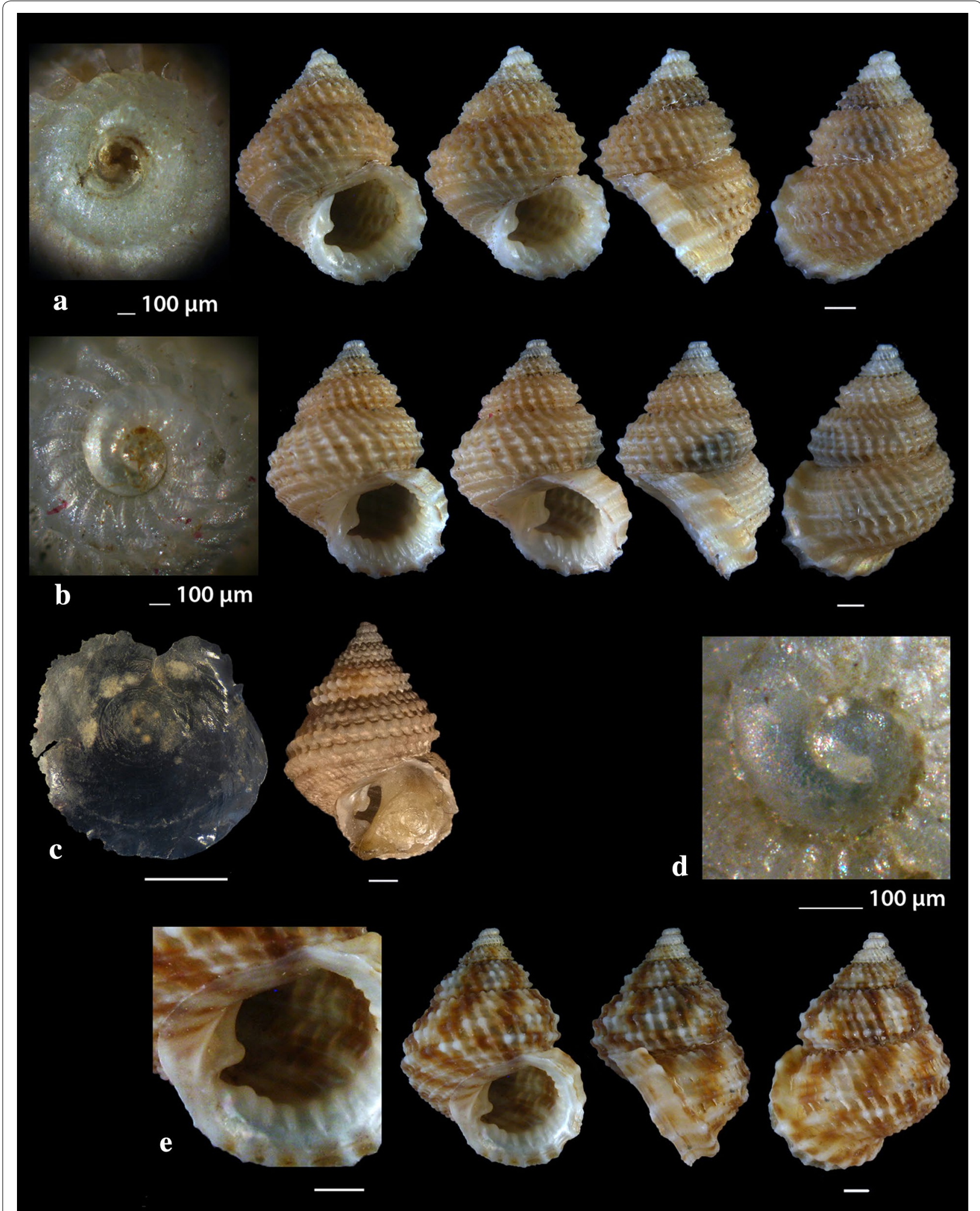

Fig. 5 a-c Danilia costellata, $\mathbf{d}-\mathbf{e}$ Danilia tinei. Bar $=1 \mathrm{~mm}$, unless otherwise indicated 

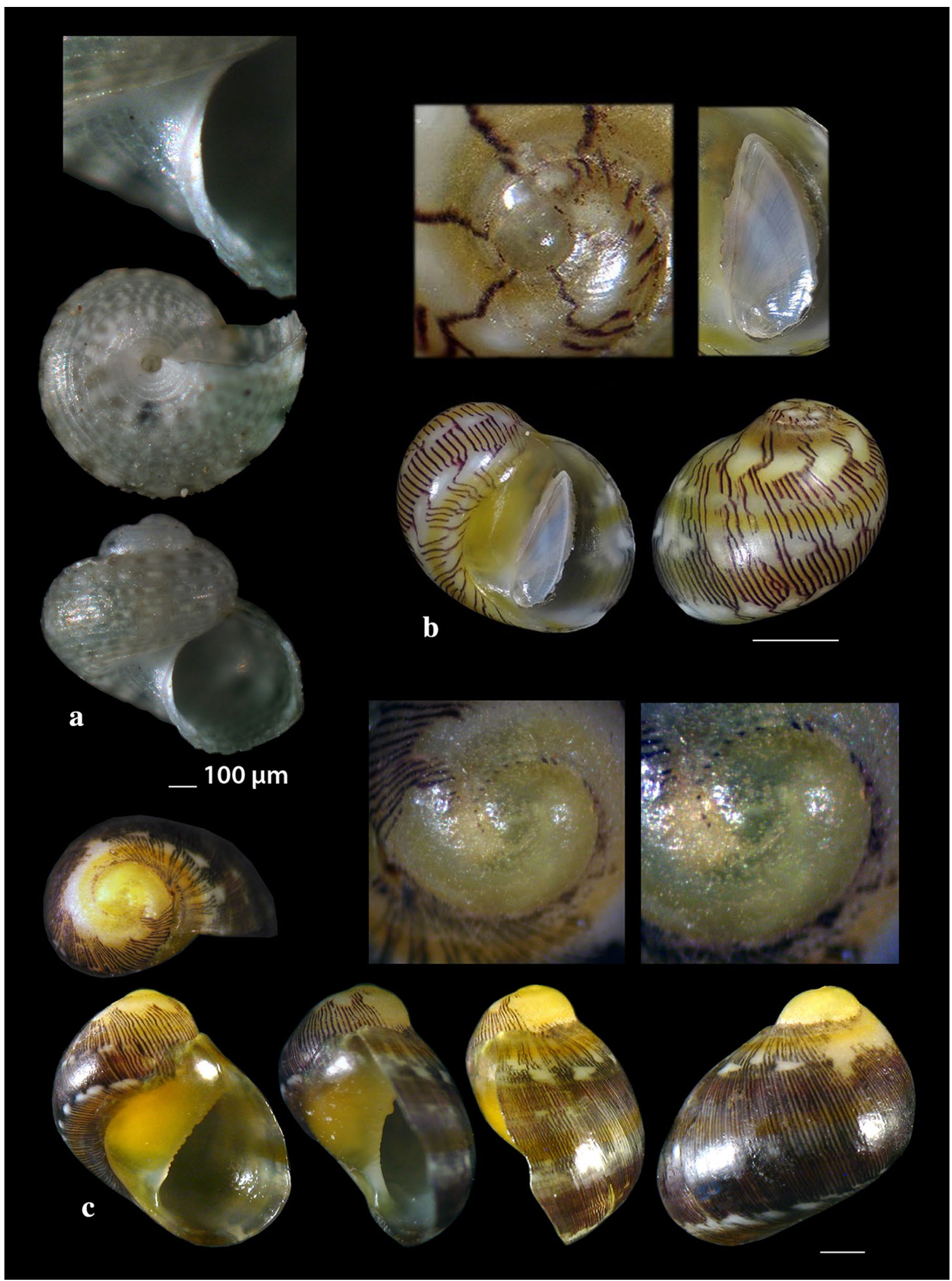

Fig. 6 a Gibbula cf. vimontiae, b, c Smaragdia souverbiana. Bar $=1 \mathrm{~mm}$, unless otherwise indicated 


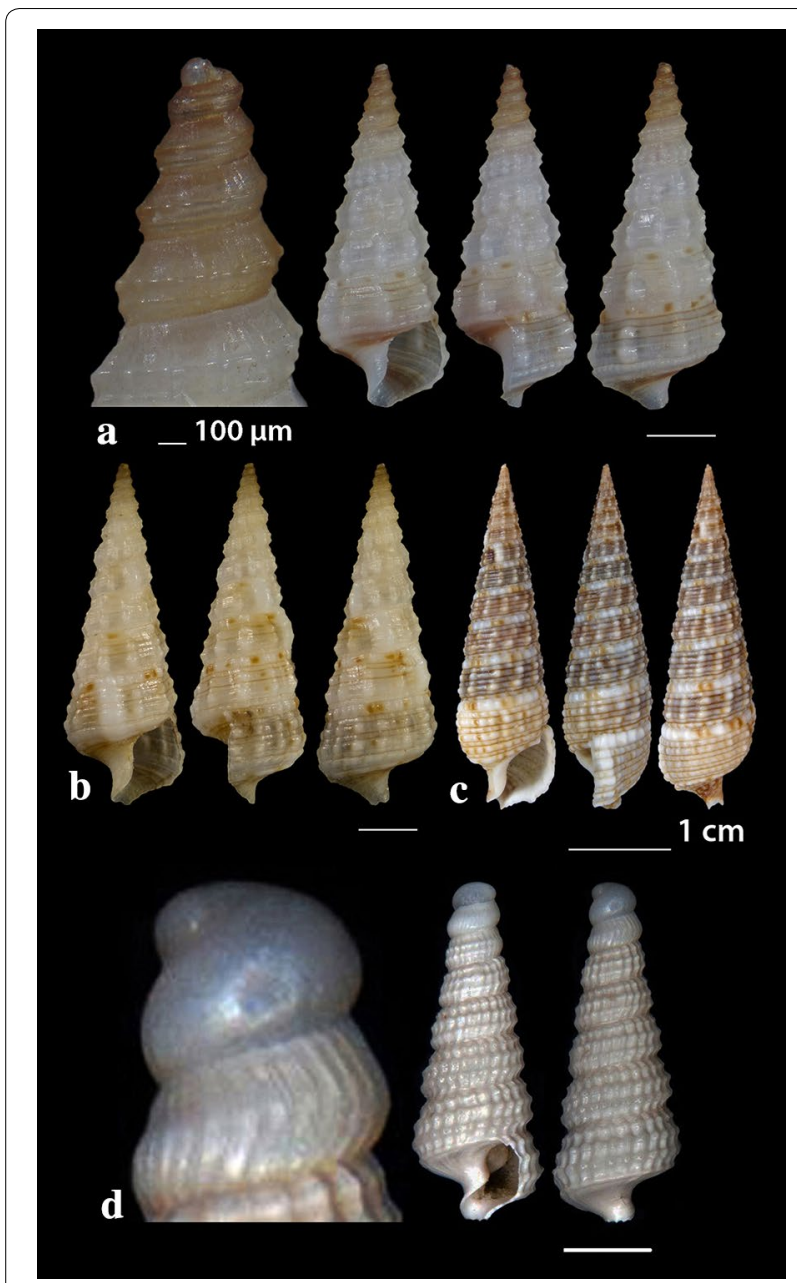

Fig. 7 a-c Rhinoclavis kochi, $\mathbf{d}$ Cerithiella metula. Bar $=1 \mathrm{~mm}$, unless otherwise indicated

Cerithiopsis petanii Prkić \& Mariottini, 2010 (Fig. 13a). One live specimen (6.70 $\mathrm{mm}$ high, $1.65 \mathrm{~mm}$ wide), $-10 \mathrm{~m}$, mixed bottom, station 5 . Known from intertidal zone of the Adriatic Sea in sponges [72].

Cerithiopsis pulvis (Issel, 1869) (Fig. 13b). Two shells both with chipped off protoconches $(2.70$ and $3.85 \mathrm{~mm}$ high, 1.00 and $1.30 \mathrm{~mm}$ wide, respectively), $-10 \mathrm{~m}$, mixed bottom, stations 20 and 21. A Lessepsian migrant in the East Mediterranean, expanded from the Israel coasts and East Aegean Sea northern up to the Black Sea $[73,74]$.

Cerithiopsis scalaris Locard, 1891 (Fig. 13c). One live specimen and nine shells $(3.00-5.45 \mathrm{~mm}$ high, $1.00-1.90 \mathrm{~mm}$ wide), $-10 \mathrm{~m}$, station 5 ; muddy bottom, $-60 \mathrm{~m}$, station 9 ; $-70 \mathrm{~m}$, rocky bottom, station 23. Uncommon, infralitoral rocky zone, associated with sponges, Mediterranean Sea [27, 35, 75, 76].

Another specimen present as C. cf. scalaris Locard, 1891 (Fig. 13d, not in Table 1) was collected, mixed bottom, $-10 \mathrm{~m}$, station 5 . It is lighter in color (honeyyellow) with the adapical cord light brown instead of unicolor and dark chestnut-brown as referred by Gofas et al. [35], and with a cylindroconical protoconch of 4.5 whorls instead of 3.5-4.0 of C. scalaris [77, 78]. Oliver et al. [79] pointed out that the teleoconch of $C$. scalaris may vary from cylindrical to cyrtocylindrical, that members of the genus Cerithiopsis with the same type of protoconch differ in their teleoconch and that cryptic species possibly exist within the C. scalaris complex.

Horologica sp. (Fig. 14a). One live specimen $(2.55 \mathrm{~mm}$ high, $0.90 \mathrm{~mm}$ wide), Aplysina aerophoba (Nardo, 1833) sponge host, $-6 \mathrm{~m}$, rocky bottom, station 16. Shell small, $\mathrm{h} / \mathrm{w}$ ratio 2.8 , fusiform, glossy, slightly scalaroid and moderately slender. Protoconch $400 \mu \mathrm{m}$ high and $220 \mu \mathrm{m}$ wide, conical, smooth, milky-white with light brown nucleus, translucent, consisting of about 4 slightly convex whorls less inflated adapically and exhibiting minute and dense dentition at the suture. Limit to the teleoconch sigmoidal. Teleoconch composed of 5.5 flat whorls with a broad base. Spiral sculpture of two wellseparated cords starting as two from the onset of the teleoconch, the adapical one being weaker in the first three whorls but becoming first equal and finally stronger in the last whorl. Two additional wide and strongly tuberculated spiral cords-peripheral and basal-and a swelling before the lower end. Axial sculpture of 14 strong, prosocline and axially aligned ribs on the body whorl, which at their intersections with the spiral cords form ovate, equidistant, conspicuous nodules with quadrangular interspaces. The nodules are elongated radially in the first four whorls and axially in the last one. Suture deep and evident separating clearly the whorls. Color walnut-brown with lighter nodules and the two basal cords darker brown. Aperture pear-shaped, wide, with white and simple outer lip. Columellar callus conspicuous, peristome thin, anal canal short and broad, siphonal canal short, open and stubby. Aperture showing by transparency the pattern of the spire. Anterior part of the animal grayish-white. The shell looks similar to Cerithiopsis minima (Brusina, 1865) in its outlook, the size and the white planktotrophic larval shell (only lacking the minute denticles in C. minima), but it bears two spiral cords as in the genus Dizoniopsis Sacco, 1895 and Horologica Laseron, 1956 [80]. It also looks similar to Dizoniopsis aspicienda Bouchet, Gofas \& Warén, 2010, but it differs mainly in the type of protoconch and the color. As members of the genus Dizoniopsis bear a stiliform or globose larval shell decorated with axial ribs or spiral cords the specimen most probably belongs to the genus Horologica Laseron, 1956, the members of which bear a smooth multispiral conical/cylindrical protoconch and 2 spiral cords per whorl [80, 81]. Oliver et al. [82] under the name 


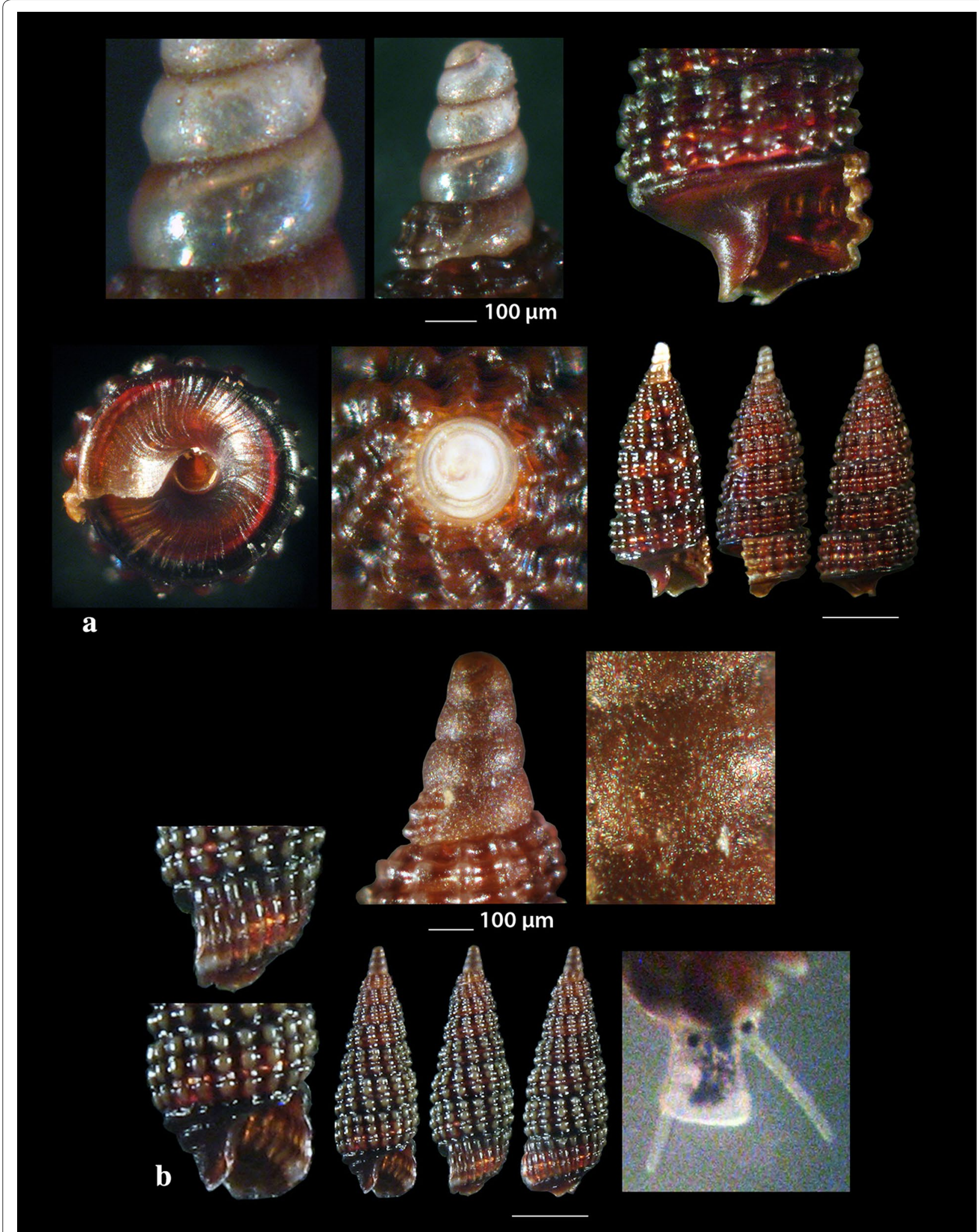

Fig. 8 a Cerithiopsis annae, b Cerithiopsis tubercularis. Bar $=1 \mathrm{~mm}$, unless otherwise indicated 


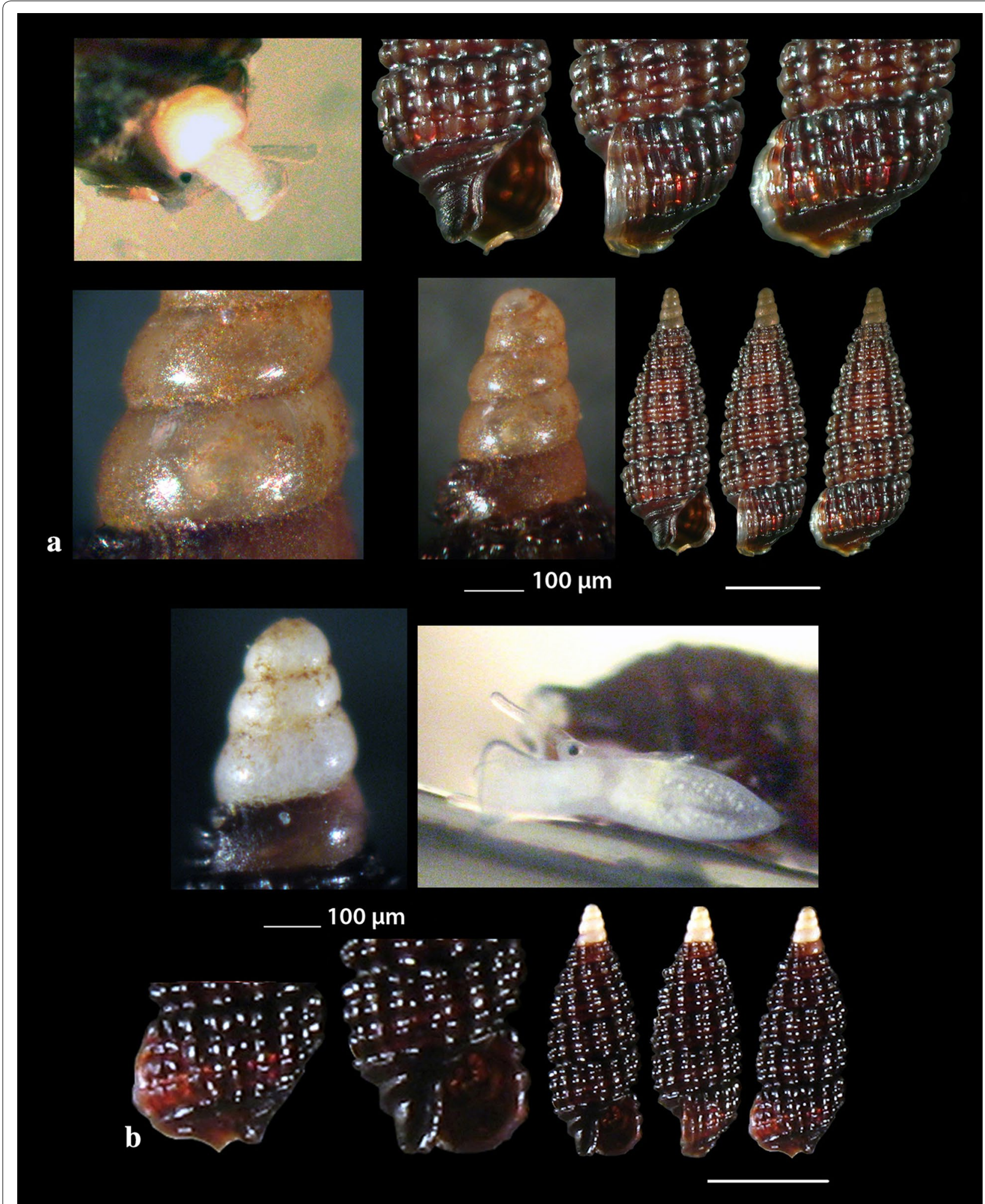

Fig. 9 a Cerithiopsis nana, b Cerithiopsis minima. Bar $=1 \mathrm{~mm}$, unless otherwise indicated 


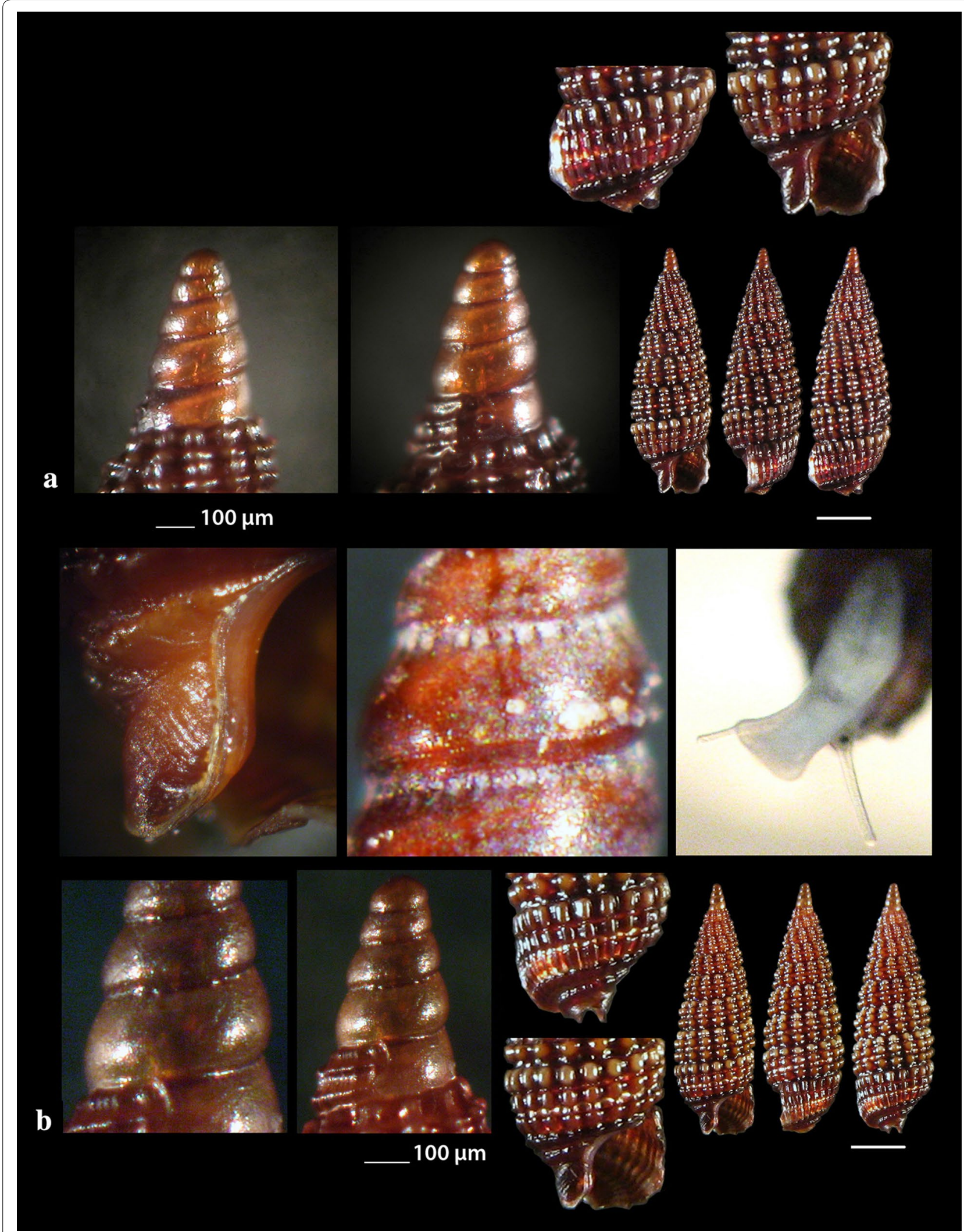

Fig. 10 a, b Cerithiopsis buzzurroi. Bar $=1 \mathrm{~mm}$, unless otherwise indicated 


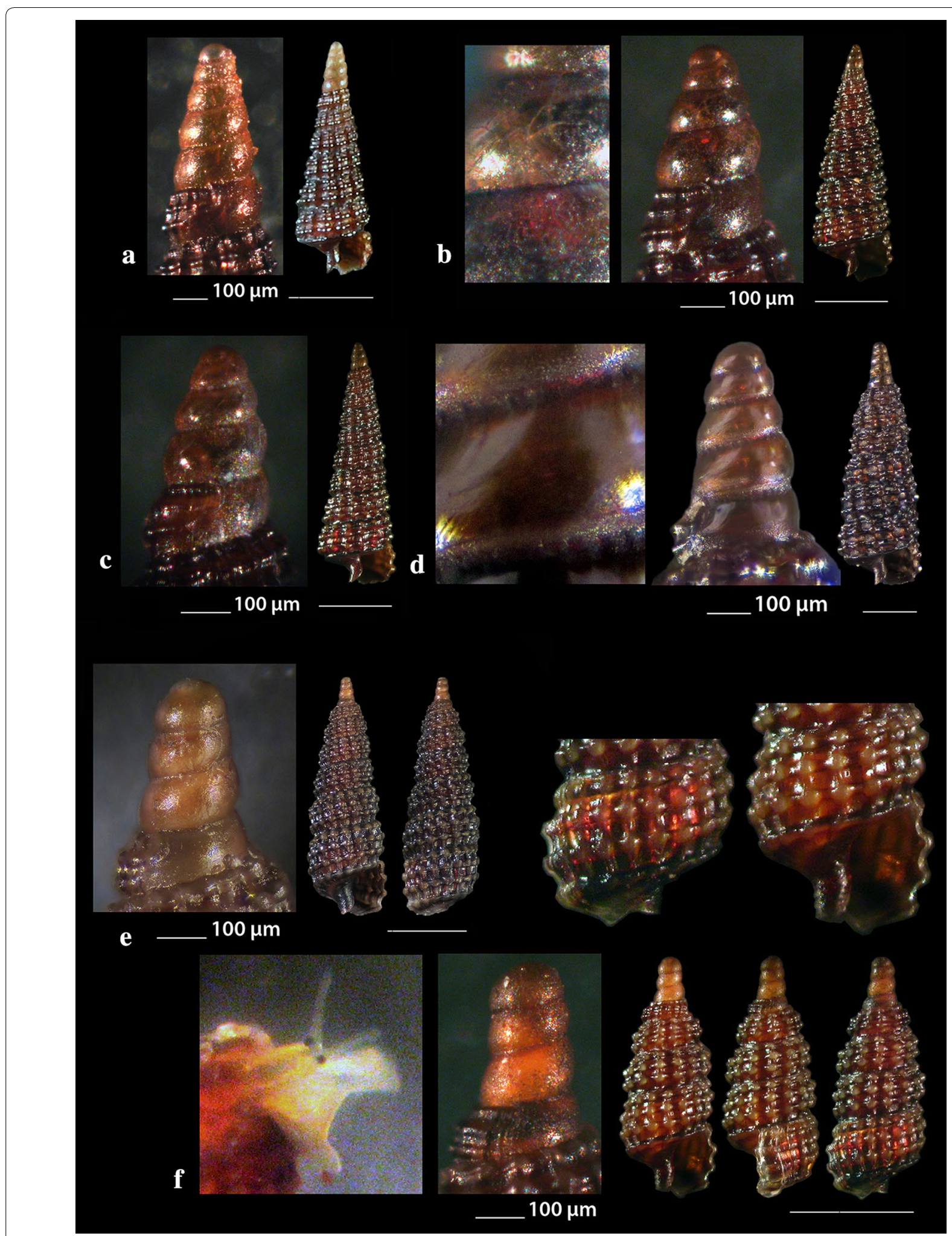

Fig. 11 a-d Cerithiopsis denticulata, e, f Cerithiopsis jeffreysi. Bar $=1 \mathrm{~mm}$, unless otherwise indicated 


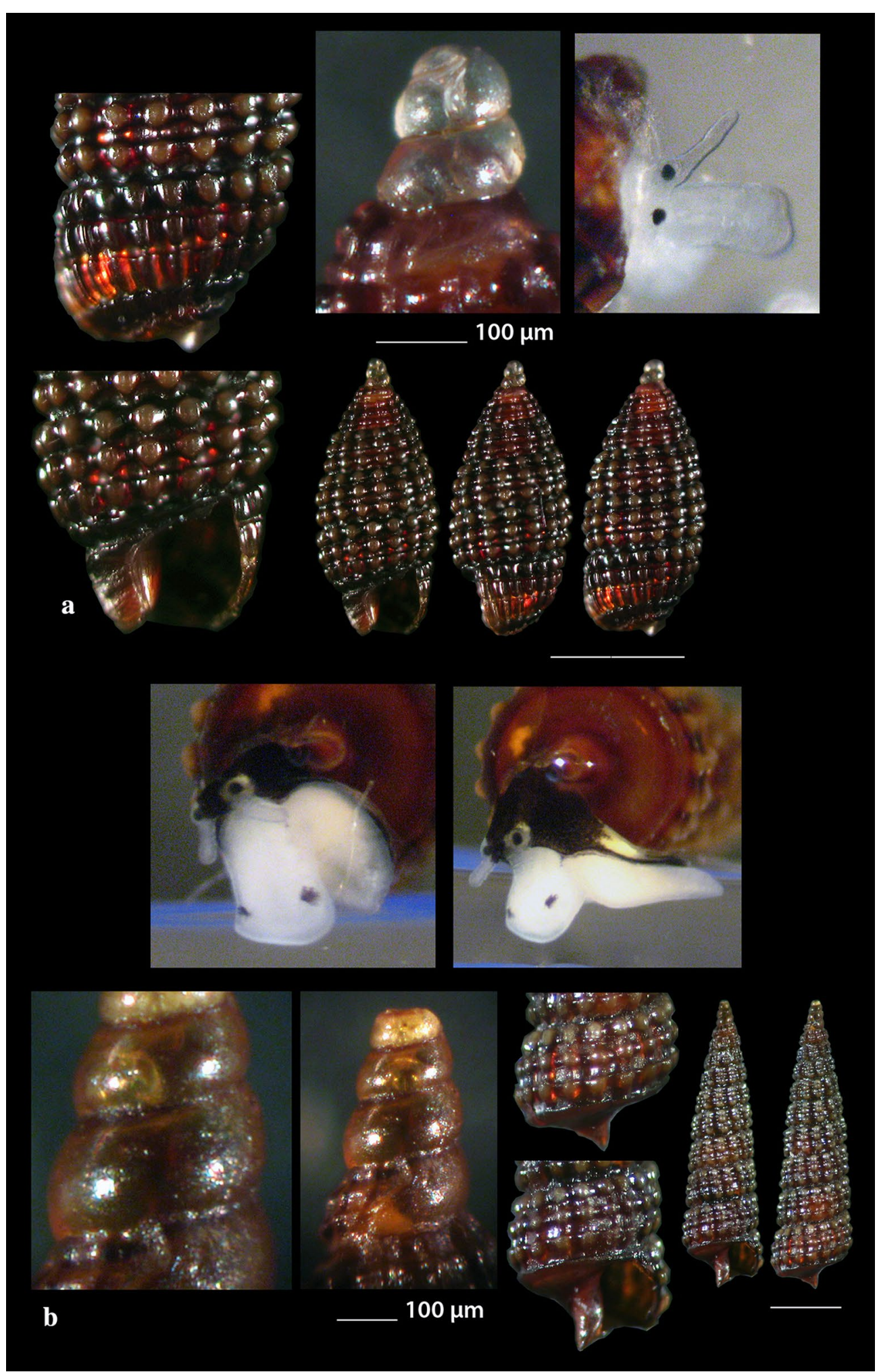

Fig. 12 a Cerithiopsis ladae, b Cerithiopsis oculisfictis. Bar =1 mm, unless otherwise indicated 


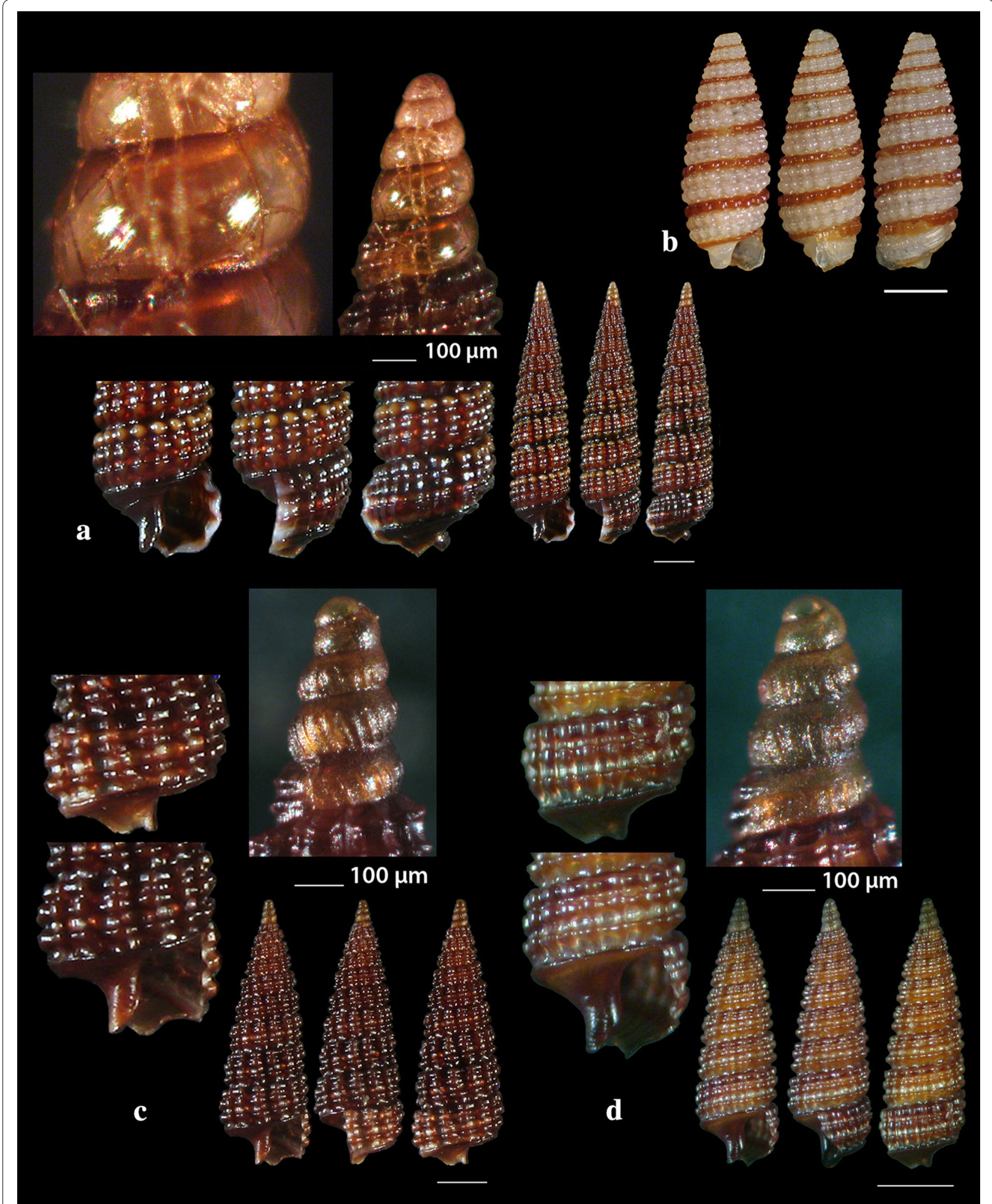

Fig. 13 a Cerithiopsis petanii, b Cerithiopsis pulvis, c Cerithiopsis scalaris, d Cerithiopsis cf. scalaris. Bar =1 mm, unless otherwise indicated 


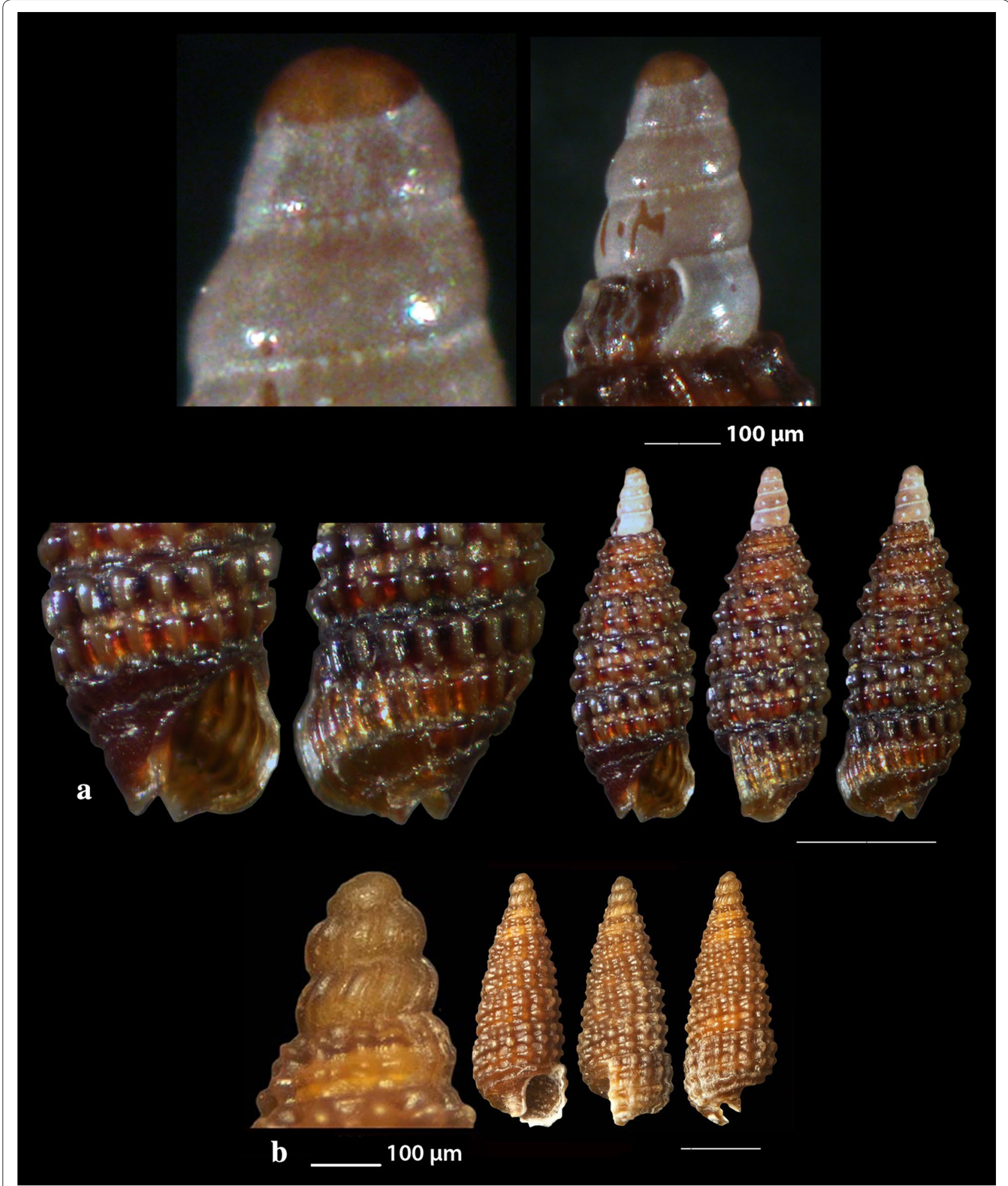

Fig. 14 a Horologica sp., b Krachia tiara. Bar $=1 \mathrm{~mm}$, unless otherwise indicated 


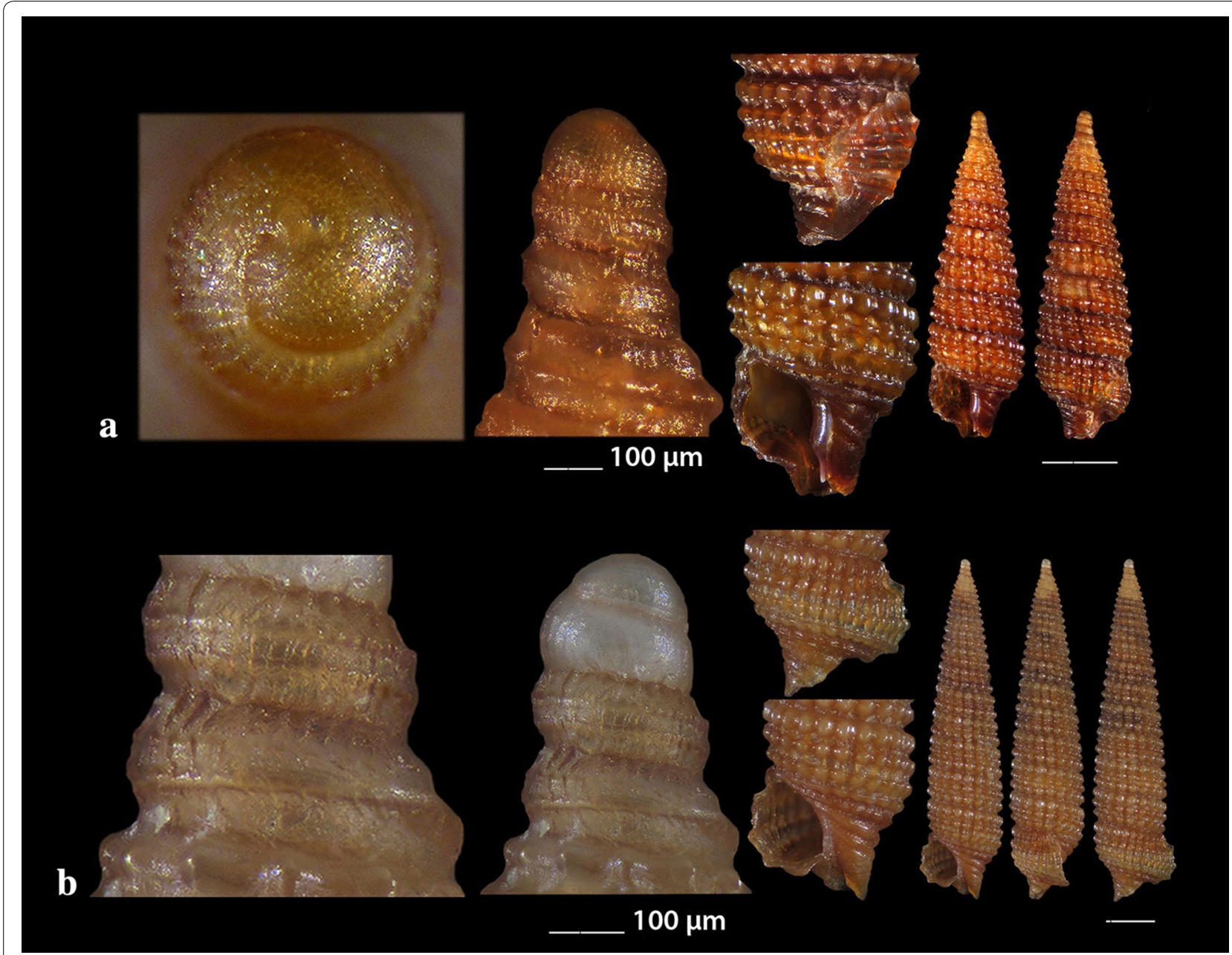

Fig. 15 a, b Monophorus amicitiae. Bar $=1 \mathrm{~mm}$, unless otherwise indicated. Specimen 15B courtesy of Panagiotis Ovalis

Dizoniopsis sp. (Figure 77 in [82]) show a quite similar to our shell, with missing protoconch, from the Chafarinas Islands, Alboran Sea. The latter authors refer that their specimen differs from the known Dizoniopsis species from the Atlantic Ocean and the Mediterranean Sea.

Krachia tiara (Monterosato 1874) (Fig. 14b). One shell (3.50 $\mathrm{mm}$ high, $1.30 \mathrm{~mm}$ wide), mixed bottom, $-80 \mathrm{~m}$, station 27. An uncommon Mediterranean species [27, 35, $47,74]$ was also recorded in East Mediterranean Sea from the Turkish coasts [54].

\section{Triphoridae Gray, 1847}

Monophorus amicitiae Romani, 2015 (Fig. 15a). One shell ( $4.30 \mathrm{~mm}$ high, $1.20 \mathrm{~mm}$ wide) from maerl beds, -70 to - 90 m, station 23; two additional shells (Fig. 15b) (7.15 and $7.40 \mathrm{~mm}$ high, 1.60 and $1.65 \mathrm{~mm}$ wide, respectively) were collected from the same station and habitat and were kindly offered by Panagiotis Ovalis to be included in this publication. Known from the infralittoral zone of the Northern Tyrrhenian Sea [83, 84].

Obesula marisnostri Bouchet, 1985 (Fig. 16a). One live mature specimen of dark chestnut-red shell $(7.55 \mathrm{~mm}$ high, $1.90 \mathrm{~mm}$ wide) and lighter apex, in whitish sponge on maerl, $-100 \mathrm{~m}$, station 23 . The easily recognizable shell has been well described [21, 35, 85] but the animal coloration was lacking until now where one live specimen has been collected. The external parts are uniformly translucent-white with cream-white spots and black eyes. The species has been referred from Greece [21] and other areas of the Mediterranean Sea [35, 77].

Strobiligera brychia (Bouchet \& Guillemot, 1978) (Fig. 16b, c). Two shells (2.20 and 14.00 high, 0.95 and $3.35 \mathrm{~mm}$ wide, respectively), $-400 \mathrm{~m}$, coralligenous bottom, station 1 . On rocky circalitoral and bathyal bottoms from the East Atlantic to the West Mediterranean Sea $[27,28,35,77]$. 


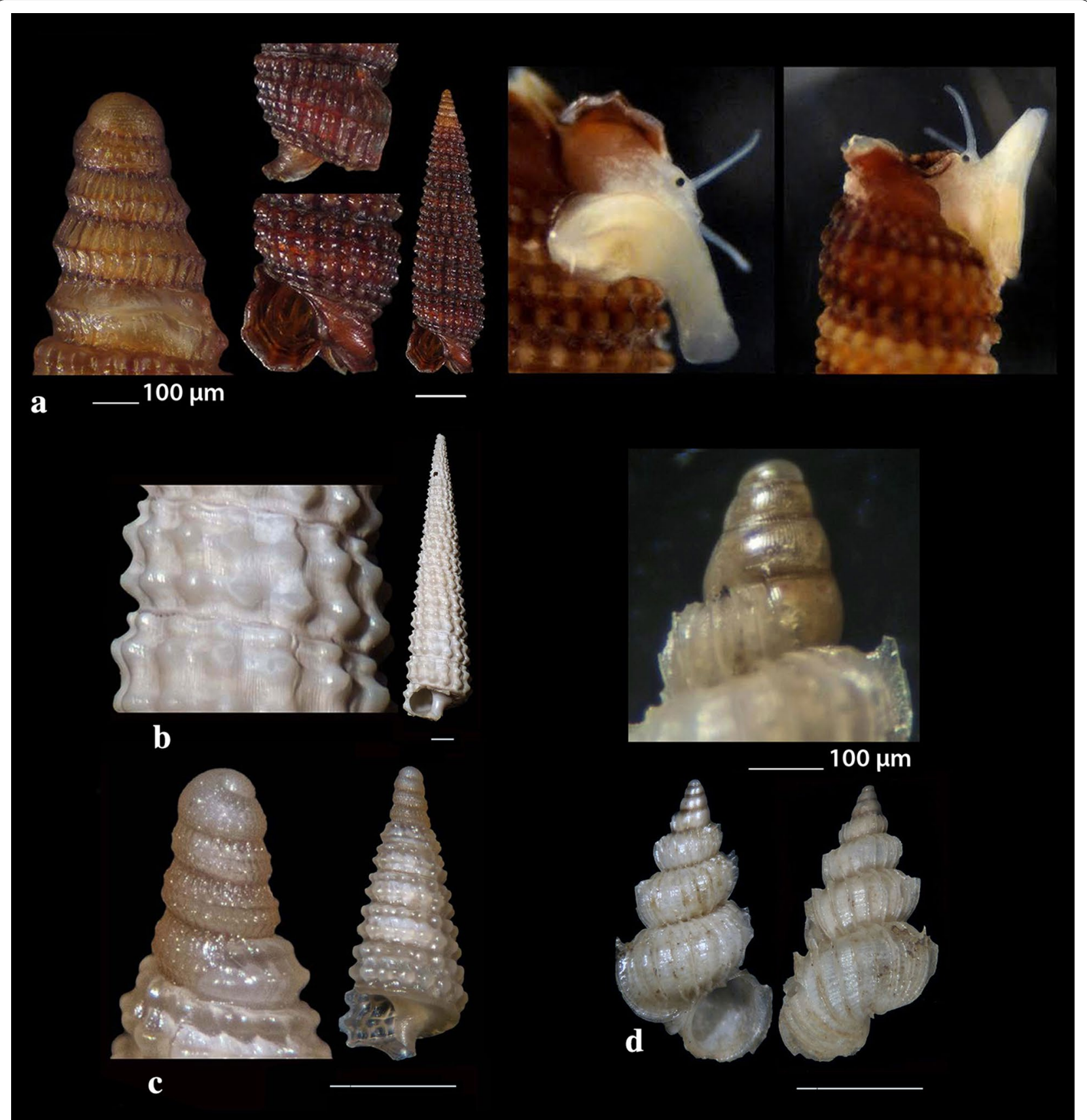

Fig. 16 a Obesula marisnostri, b, c Strobiligera brychia, $\mathbf{d}$ Epitonium tryoni. Bar $=1 \mathrm{~mm}$, unless otherwise indicated

\section{Epitoniidae Berry, 1910 (1812)}

Epitonium tryoni (de Boury, 1913) (Fig. 16d). One shell (2.30 $\mathrm{mm}$ high, $1.10 \mathrm{~mm}$ wide), trawled, rocky bottom, - $200 \mathrm{~m}$, station 30. Uncommon, NE Atlantic and West Mediterranean Sea [27, 36, 74, 86].

Janthina pallida W. Thompson, 1840 (Fig. 17a). Several shells (12.90-17.00 $\mathrm{mm}$ high, 11.95-15.75 mm wide), beached, station 28. A cosmopolitan species frequently beached in the Mediterranean Sea [27, 35, 36] but rare in the Maltese waters [44].

Opalia crenata (Linnaeus, 1758) (Fig. 17b). One live specimen and six shells (10.50-17.00 m high, 4.15$6.69 \mathrm{~mm}$ wide), beached, 5-10 $\mathrm{m}$ of mixed bottom, station 29. It is an uncommon amphiatlantic and Mediterranean species of shallow waters $[27,35,36]$ associated with Anemonia sulcata [35]. 


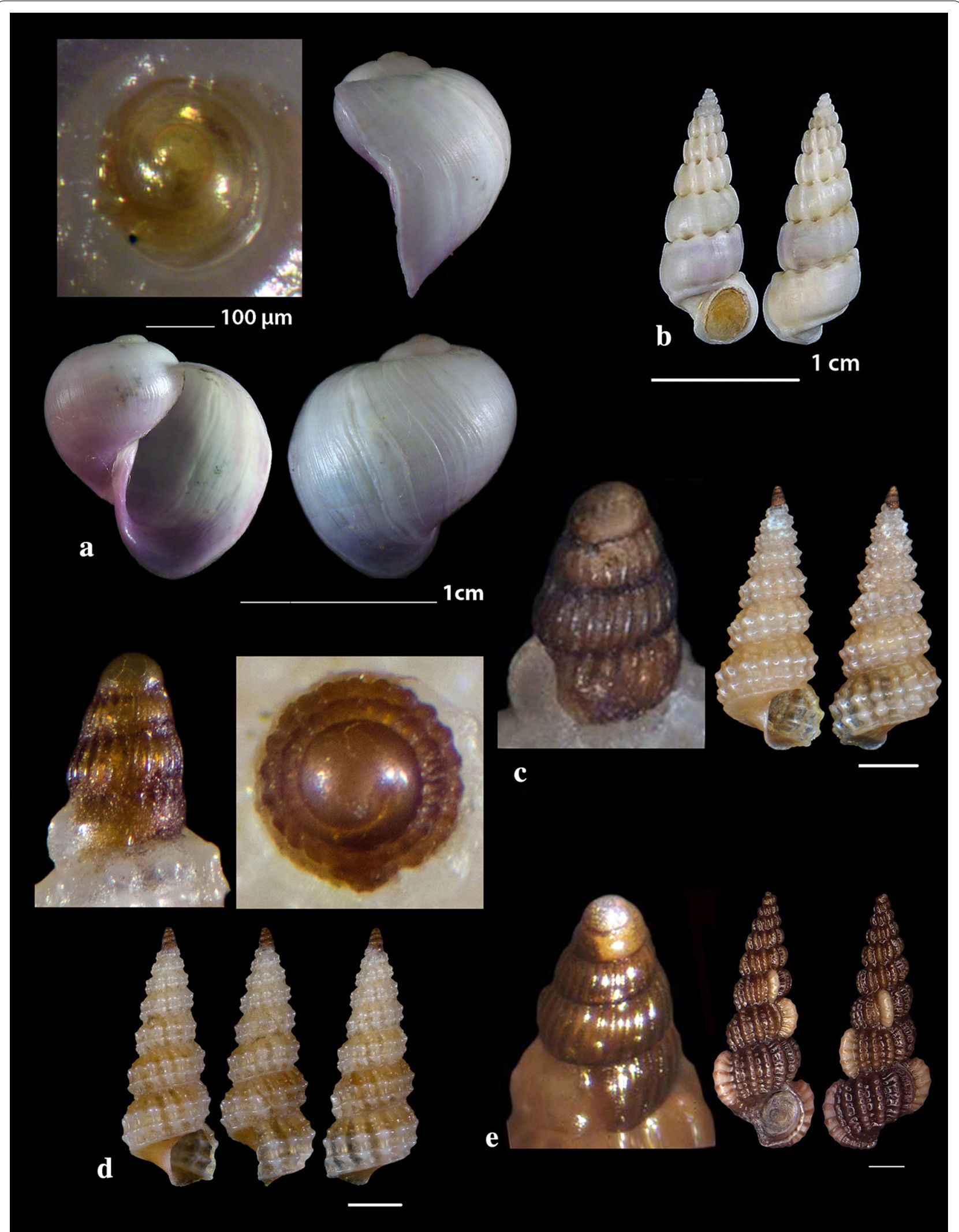

Fig. 17 a Janthina pallida, b Opalia crenata, c, d Narrimania concinna, e Opaliopsis atlantis. Bar = $1 \mathrm{~mm}$, unless otherwise indicated 


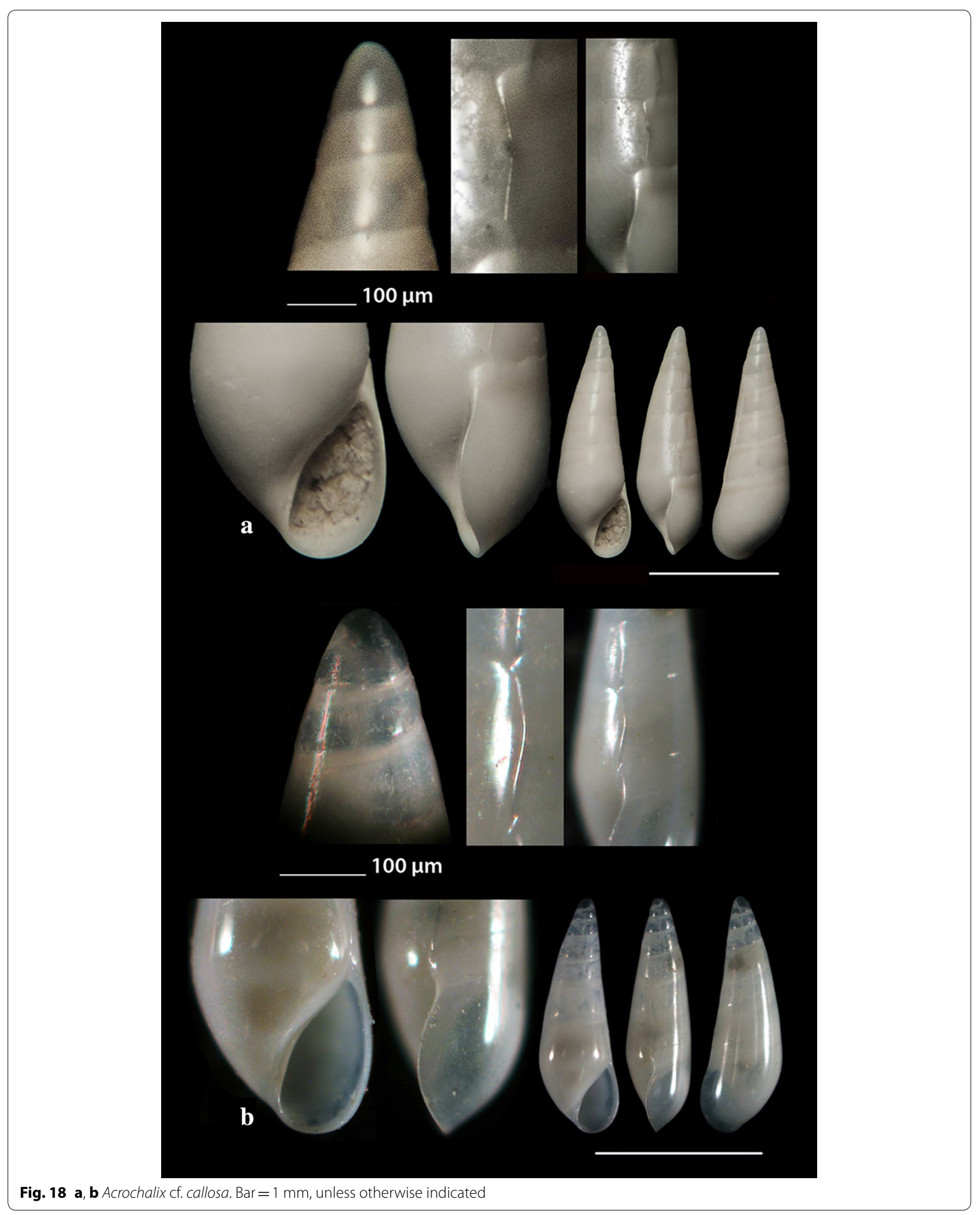




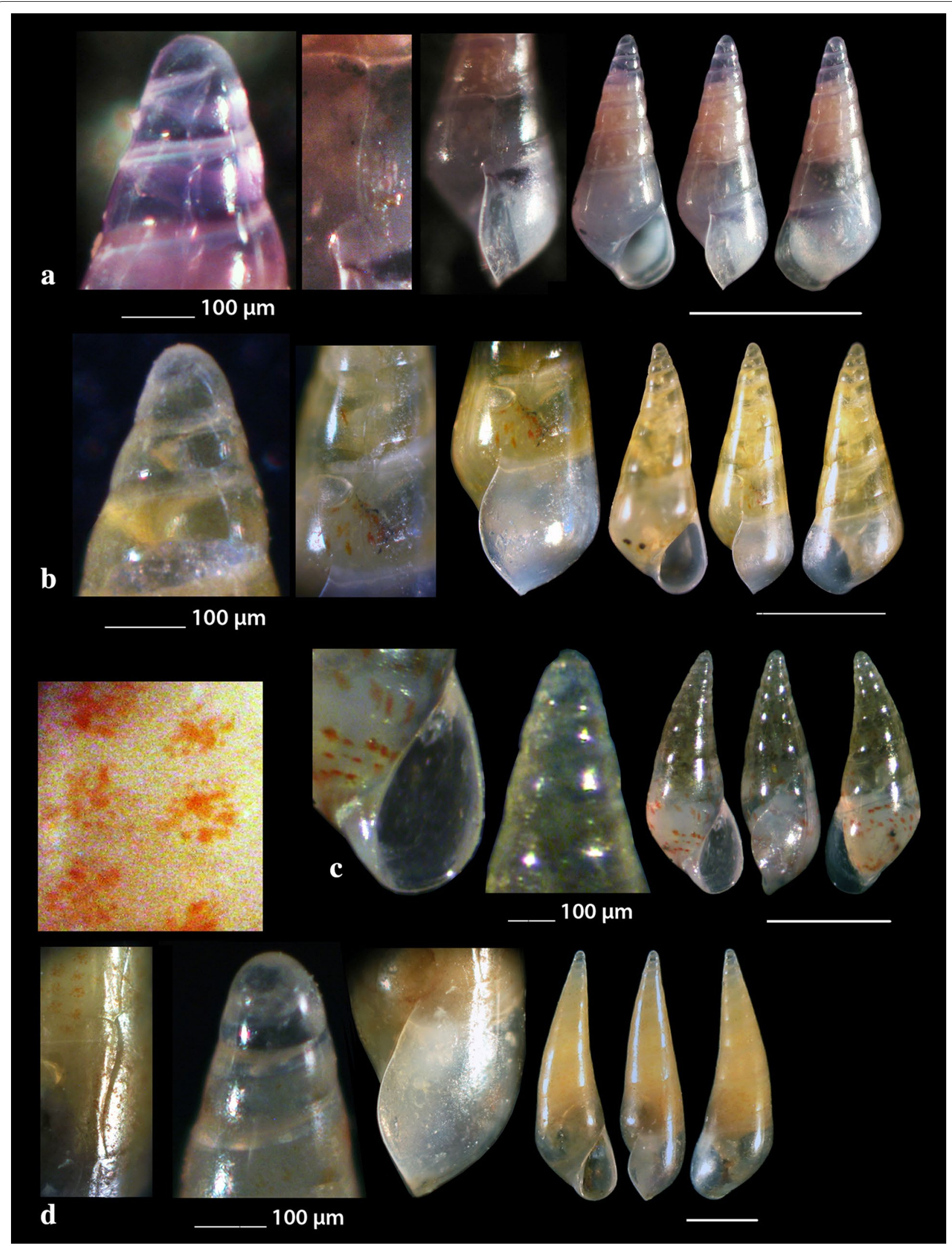

Fig. 19 a Campylorhaphion cf. famelicum, b Melanella spiridioni, c, d Curveulima dautzenbergi. Bar $=1 \mathrm{~mm}$, unless otherwise indicated 


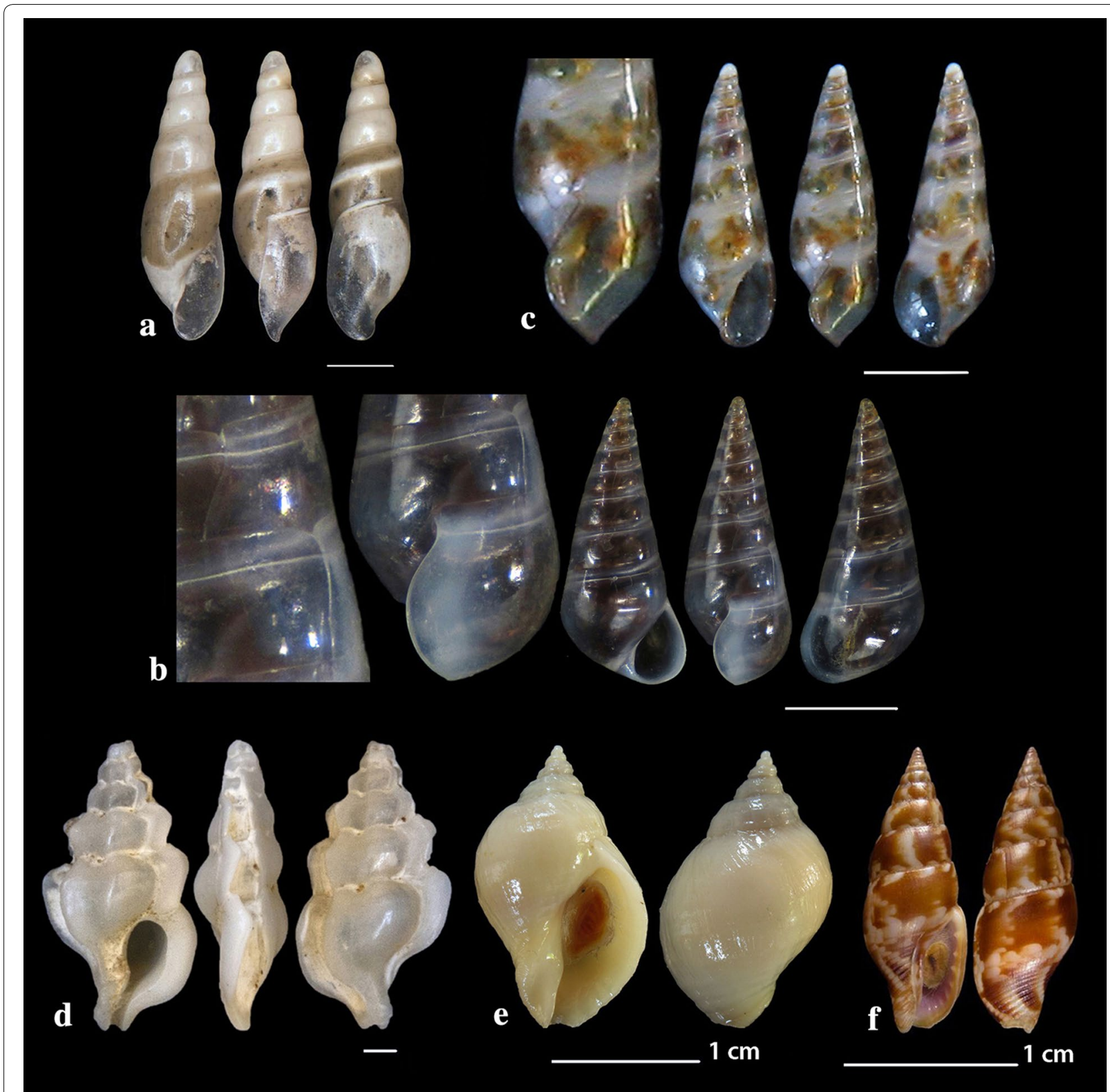

Fig. 20 a Haliella stenostoma, b Nanobalcis nana, c Sticteulima jeffreysiana, d Aspella anceps, e Nucella lapillus, $\mathbf{f}$ Mitrella pallaryi. Bar $=1 \mathrm{~mm}$, unless otherwise indicated

\section{Nystiellidae Clench \& Turner, 1952}

Narrimania concinna (Sykes, 1925) (Fig. 17c, d). One live specimen and one shell (4.10 and $4.90 \mathrm{~mm}$ high, 1.55 and $1.80 \mathrm{~mm}$ wide, respectively) $-135 \mathrm{~m}$, station $10 ;-90 \mathrm{~m}$, hard substrate, station 23. Rare, South and Central Mediterranean and Atlantic $[27,86,87]$.

Opaliopsis atlantis (Clench \& Turner, 1952) (Fig. 17e). One live specimen and five shells $(4.00-9.00 \mathrm{~mm}$ high, 1.20-3.50 mm wide), $-200 \mathrm{~m}$, rocky bottom, station 1 and $-400 \mathrm{~m}$, coralligenous bottom, station 2 . Very rare in the Mediterranean Sea, less rare in Cuba, Florida and the Azores [27, 35, 44, 86, 88-90].

\section{Eulimidae Philippi, 1853}

Acrochalix cf. callosa Bouchet \& Warén, 1986 (Fig. 18a, b). Two shells ( 1.40 and $1.85 \mathrm{~mm}$ high, 0.50 and $0.60 \mathrm{~mm}$ wide, respectively), $-450 \mathrm{~m}$, station $1 ;-70 \mathrm{~m}$, station 10 . The solid, pointed and gently curved shell bears a conical 


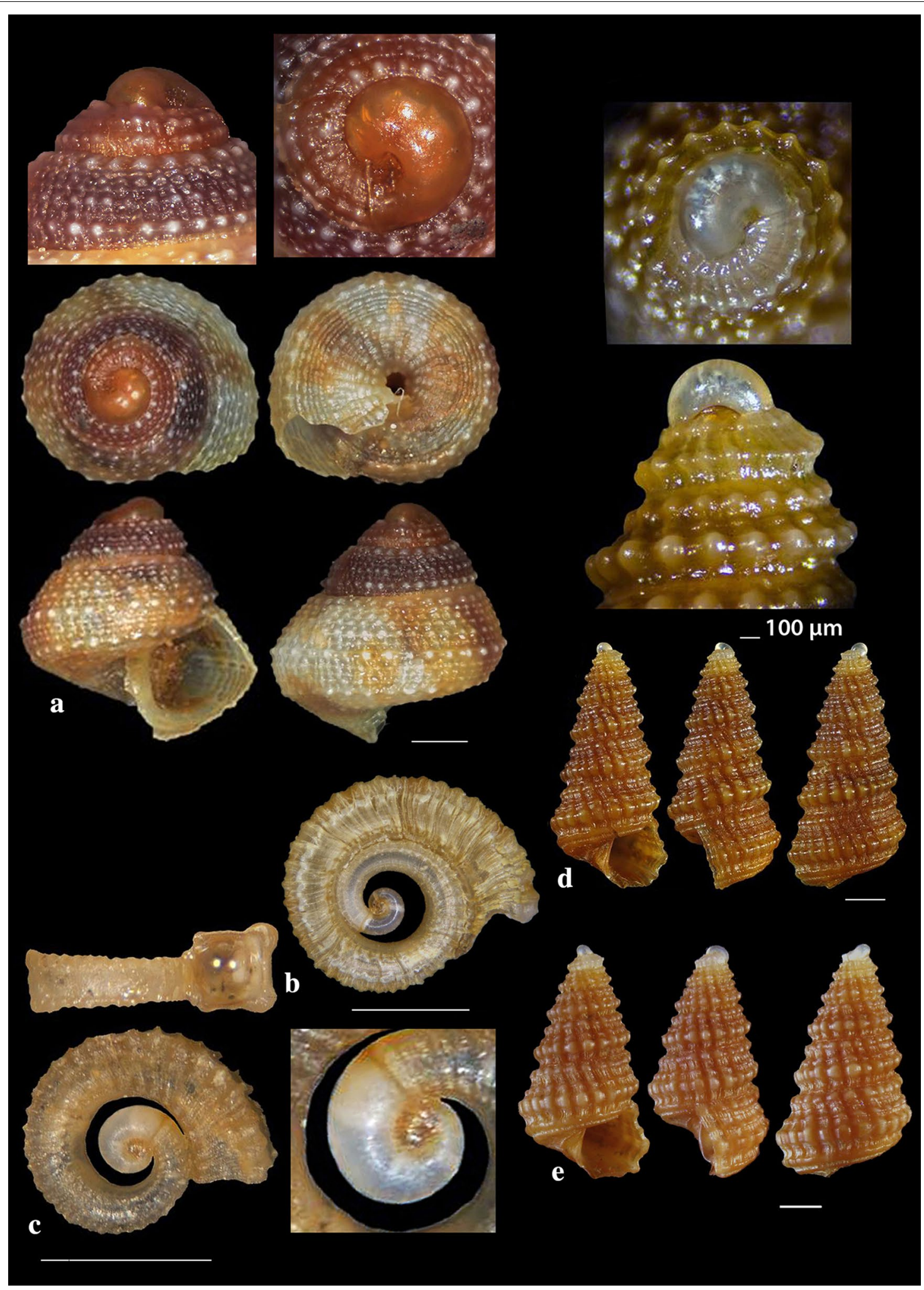

Fig. 21 a Heliacus jeffreysianus, b, c Spirolaxis clenchi, d, e Mathilda coronata. Bar =1 mm, unless otherwise indicated 
protoconch. The later has a bluntly rounded initial whorl, a visible limit with the teleoconch, consists of 2.5 evenly convex whorls, is $260 \mu \mathrm{m}$ high and $185 \mu \mathrm{m}$ wide. The teleoconch bears 6 perfectly smooth and nearly flat whorls of gradually increasing diameter and an evenly curved axis. Suture very indistinct while the incremental growth scars of all 6 whorls are strictly aligned, forming thus a perfect series oriented towards the upper right of the shell. The right side of the shell is almost straight. The shell is flattened dorso-ventrally with the diameter from the outer lip to the opposite side of the shell measuring $578 \mu \mathrm{m}$ and that at a right angle to this measuring $522 \mu \mathrm{m}$. The relation is 0.90 . The last whorl occupies nearly $50 \%$ of the shell's length. Aperture high and pyriform with its long axis towards the right, outer lip orthocline joining the suture at a right angle but slightly bending to the right at its high most end and slightly projecting at its lower part and at 2/5 of its height. Inner lip reflected both on the columella and the parietal wall forming a continuous callus while the columella is straight in its upper part, is curved in its lower part and continuous with the parietal wall. Outer lip sinuous at its vicinity with the suture. Acrochalix callosa is reported as a NE Atlantic species and differs from other Mediterranean minute and curved species by having a slender aperture, a straighter columella-parietal wall line and a well-developed, solid and continuous inner lip [86]. As the species is very rare and its variability unknown, we refer to our specimens as $A$. cf. callosa.

Campylorhaphion cf. famelicum (Watson, 1883) (Fig. 19a). One young live specimen $(1.50 \mathrm{~mm}$ high, $0.60 \mathrm{~mm}$ wide), on Holothuria (Holothuria) tubulosa Gmelin, 1791 host, -35 m, mixed bottom, station 4. The hyaline, white, club-shaped shell has a paucispiral protoconch of 2 whorls (excluding the nucleus) and a diameter of approximately $200 \mu \mathrm{m}$. The suture of the protoconch whorls exhibits a weak and dense crenulation. The teleoconch is slightly curved, of 5 shiny whorls that are nearly smooth though with very fine axial sculpture approximately $30 \mu \mathrm{m}$ apart that is more prominent close to the incremental scars (Fig. 19a). The body whorl occupies $48 \%$ of the shell's length and forms a rounded base, while the aperture is nearly twice as high as wide and occupies $34 \%$ of the shell's length. Its Vitreolina type incremental scars are not strictly aligned, are facing the lateral side of the shell over the outer lip with the two last scars (above the outer lip) in a slowly retreating series, nearly aligned with the outer lip and the two adapical (older ones) in advancing series, while the oldest one is more conspicuous. The inner lip is straight by the columella and projected over its lower part, while the outer lip is arquated and orthocline. Animal of light pink-purple color. We did not manage to find in the literature a description of a specimen of the same developmental stage as ours, therefore, we present the later as $C$. cf. famelicum. The specimen resembles Melanella spiridioni (Dautzenberg \& H. Fisher, 1896) (Fig. 19b) from which it differs in having a cylindrical protoconch instead of a conical of M. spiridioni and a more fragile teleoconch, in its aperture which is, at least, twice as high as wide and in the color of the animal which is lemon-yellow with red speckles in $M$. spiridioni. It differs from the Vitreolina species in having a cylindrical protoconch with almost $2^{1 / 2}$ whorls. Campylorhaphion famelicum is uncommon in the Central Mediterranean Sea [27] and in the North Atlantic [86].

Curveulima dautzenbergi (Pallary, 1900) (Fig. 19c, d). Four live specimens and two shells $(1.50-3.50 \mathrm{~mm}$ high, $0.60-1.15 \mathrm{~mm}$ wide), detritus material, $-40 \mathrm{~m}$, mixed bottom, station 3. Uncommon, in subtidal rocky bottoms parasitizing crinoids of the genus Antedon in the Atlantic and the West Mediterranean Sea [35, 91].

Haliella stenostoma (Jeffreys, 1858) (Fig. 20a). One shell (4.30 mm high, $1.30 \mathrm{~mm}$ wide), $-400 \mathrm{~m}$, coralligenous bottom, station 1. A rare North Atlantic and Mediterranean species of muddy circalittoral and bathyal planes [27, 86, 92, 93].

Nanobalcis nana (Monterosato, 1878) (Fig. 20b). 12 live individuals and several shells $(2.00-2.45 \mathrm{~mm}$ high, 0.90-1.10 mm wide), mixed bottom, -40 to $-120 \mathrm{~m}$, station 13 ; -40 to $-70 \mathrm{~m}$, kelps, station 23 . Up to 2001 , the species was recorded only in the Central Mediterranean [94] but eventually was found by Öztürk et al. [54] in the Turkish coast of the SE Aegean Sea. It is characterized as uncommon $[27,35]$ in the Mediterranean Sea and is a parasite of sea urchins [35, 94].

Sticteulima jeffreysiana (Brusina, 1869) (Fig. 20c). Seven live specimens and 10 shells $(2.25-2.70 \mathrm{~mm}$ high, 0.70-0.95 mm wide), from mixed bottoms $-70 \mathrm{~m}$, station 6 ; $-40 \mathrm{~m}$, station $10 ;-30 \mathrm{~m}$, station $11 ;-30 \mathrm{~m}$, station $12 ;-60 \mathrm{~m}$, station $13 ;-40$ to $-50 \mathrm{~m}$, mixed bottom with kelps, station 23 , were all collected from detritus material. The species is distributed all over the Mediterranean Sea [27, 35, 44] and from the Hellenic Seas it was referred from the South Aegean Sea [16].

\section{Muricidae Rafinesque, 1815}

Aspella anceps (Lamarck, 1822) (Fig. 20d). Six shells (7.00-11.00 mm high, $3.50-5.00 \mathrm{~mm}$ wide), -6 to $-10 \mathrm{~m}$, mixed bottom, station 21. A rare and characteristic inhabitant of the East Mediterranean [27].

Nucella lapillus (Linnaeus, 1758) (Fig. 20e). Two live specimens (18.65 and $25.70 \mathrm{~mm}$ high, 11.60 and $15.70 \mathrm{~mm}$ wide, respectively), detritus material, $-10 \mathrm{~m}$, mixed bottom, station 8 . Uncommon, carnivorous, West and Central Mediterranean [27, 35, 47]. 


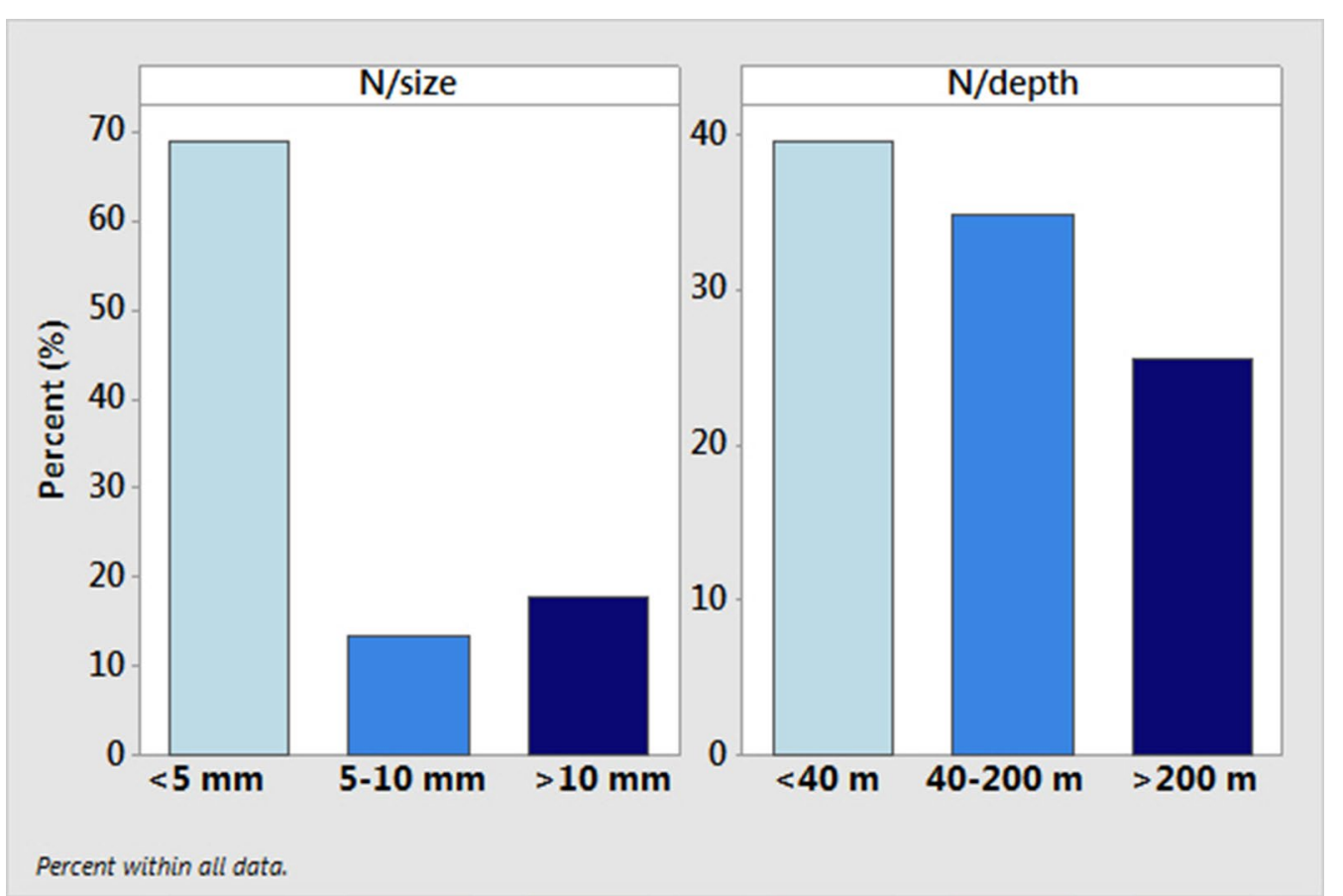

Fig. 22 Percentage of species number (N) per size and depths of collection

\section{Columbellidae Swainson, 1840}

Mitrella pallaryi (Dautzenberg, 1927) (Fig. 20f). Four live specimens and three shells (15.00-18.00 mm high, 5-6 mm wide), biogenic substrate, -30 to $-70 \mathrm{~m}$, station 23. Uncommon, Mediterranean, coralligenous, sandy and muddy circalittoral and bathyal bottoms from 30 to $250 \mathrm{~m}[27,35]$.

\section{Architectonicidae Gray, 1850}

Heliacus jeffreysianus (Tiberi, 1867) (Fig. 21a). One live specimen ( $3.75 \mathrm{~mm}$ high, $3.85 \mathrm{~mm}$ wide), $-100 \mathrm{~m}$, maerl, station 16 . $H$. jeffreysianus is an extremely rare architectonicid in the Mediterranean Sea and worldwide [95-97].

Spirolaxis clenchi Jaume \& Borro, 1946 (Fig. 21b, c). Two shells (0.50 and $0.75 \mathrm{~mm}$ high, 1.50 and $2.30 \mathrm{~mm}$ wide, respectively), coralligenous bottom, $-400 \mathrm{~m}$, station 1. Rare species of the deep and bathyal Atlantic and Mediterranean [27, 35, 98].

\section{Mathildidae Dall, 1889}

Mathilda coronata Monterosato, 1875 (Fig. 21d, e). Two shells (4.95 and $6.35 \mathrm{~mm}$ high, 2.75 and $2.95 \mathrm{~mm}$ wide, respectively), -80 and $-120 \mathrm{~m}$, biogenic substrate and maerl, stations 16 and 31. Rare, circalittoral and bathyal, Mediterranean [27, 35].

\section{Discussion}

Out of the 45 presented species, 40 are reported for the first time for the Hellenic fauna, raising its gastropod biodiversity from 651 [21] to 691 species, and 17 species are new records for the East Mediterranean Sea. Two families and 19 genera are also new records for the Hellenic fauna (see Table 1). Interestingly, the vast majority of the presented species is of minute size (nearly 70\%) being collected from a variety of substrates and depths (Fig. 22).

The occurrence of only shells and among them juvenile ones of Rhinoclavis kochi accumulated in shallow water stations, could be explained by an initial rapid increase of the population density followed by a decline due to the sea temperature change [5] and subsequent accumulation of the shells by the sea currents. This may also mean a temporal establishment. A future occurrence of live specimens could not be excluded provided the environmental conditions are favorable and the corridors are open.

The almost simultaneous findings of Cerithiopsis buzzurroi, C. ladae, C. scalaris, Narrimania concinna, Nanobalcis nana and Sticteulima jeffreysiana from different areas of Greece indicates that they are more widely distributed in the Hellenic Seas and the Eastern Mediterranean Sea, and that targeted researches from the same type of substrates and direct sampling might bring to light more species. 
Field observations and the gross anatomy of their alimentary systems indicate that ptenoglossans are parasites [99]. Among them, cerithiopsids are usually associated with sponges while eulimids have a strict preference for certain classes of echinoderms [99]. At the same time the identification of cerithiopsids, in particular, necessitates the presence of intact protoconches and/or the observation of the color of the living animal and thus, the collection of live specimens. In the present study we have met those prerequisites by means of brushing their hosts and by keeping the animals alive until they were photographed.

After an extended survey of the literature on Eritrean and Indo-Pacific Triphorids and the lack, up to now, of intermediate records of $M$. amicitiae from the East Mediterranean Sea [83] almost rules out an Eritrean or IndoPacific origin of the species. The present new records from Greece, although cannot challenge that hypothesis, are indicative of a wider range of distribution.

The assignment of our specimen Horologica sp. to the genus Horologica Lasero, 1956 was based primarily upon the combination of its smooth protoconch (characteristic for the genera Cerithiopsis sp., Horologica sp. and Joculator sp.) and its spiral sculpture of 2 cords (genera Dizoniopsis sp., Mentax sp. and Prolixodens sp.). Cerithiopsis sp. and Joculator sp. were excluded as they bear 3 spiral cords while Dizoniopsis sp., Mentax sp. and Prolixodens sp. were excluded on the bases of their ribbed protoconches [80]. We hope that further and persistent efforts will bring to light more specimens to study the variability of the species and perhaps describing a new taxon.

The occurrence of Heliacus jeffreysianus in the Hellenic waters, besides the record from South Crete [97] considerably enlarges its distribution, which, apart from its extreme rarity, is indicative of a rather broad range of occurrence. The large hyperstrophic protoconch of about $1 \mathrm{~mm}$, fitting the size range of those species with a planktotrophic development, supports the hypothesis of a potentially wide geographical distribution [100]. To our knowledge, the scattered occurrence and extreme rarity of $H$. jeffreysianus may be attributed to its cryptic life-style which may be intimately linked to a deep water zoanthid host, typical of some offshore bottoms [96].

\section{Conclusions}

45 species, the majority of which is of minute size, belonging to 19 families were identified. Among those species, 17 are new for the Eastern Mediterranean Sea and 40 are new for the Hellenic fauna. The high number of new findings is attributed to the sampling methods applied, the under- or unsearched marine environments investigated, as well as the different types of substrates and depths covered, and the multilateral co-operation.

\section{Methods}

The sampling and handling of the specimens were conducted according to Manousis and Galinou-Mitsoudi [21] from October 2008 to March 2017 in certain locations throughout the Hellenic Seas (Fig. 1). In addition, we have applied: (a) brushing with a soft brush on holothurians, sea urchins and sponges either in situ or on live material brought temporarily to the surface in several localities and from various habitats, (b) sampling vertical substrates (e.g. poles, embankments) by means of a metal pole scraper connected to a $120 \mu \mathrm{m}$ mesh nylon net, (c) keeping until examined and sorting out benthic material in cool sea water until photography of live specimens took place. Cooling of biological material in the sea water was achieved by means of a gel freeze ice pack under the examination vessel.

The protoconch whorls were counted according to Verduin [101], the protoconch's visible height was measured parallel to its axis, from the tip to the intersection of the larval scar and the teleoconch suture, while for the shell's slenderness $(\mathrm{h} / \mathrm{w})$ the outer lip of the aperture was included in the shell's width.

The species recognition was based on: (a) systematic guides and atlases (e.g. [5, 27, 29, 35]); (b) faunistic and review articles $[76,102]$, (c) studies on the Mollusca fauna in the Hellenic seas [18, 21, 103]. Information from specific web sites was also taken into account (31 March 2017). More specifically, for the species nomenclature update, besides the Marine Biodiversity and Ecosystem Functioning EU Network of Excellence (MarBEF) [58] and the World Register of Marine Species (WoRMS) [104] the Taxonomic on-line Database on European Marine Mollusca (CLEMAM) [34] was used. In addition, the Ellenic Network on Aquatic Invasive Species (ELNAIS) [61] and the Marine Mediterranean Invasive Alien Species database (MAMIAS) [105] were used for the alien species status in the Hellenic and Mediterranean Seas. Records were compared with the checklist of Koukouras [106]. For the molluscan life habits, the Todd databases [107] were taken into account. The specimens are deposited in the premises of the Alexander Technological Educational Institute of Thessaloniki and those of Dr. T. Manousis, C. Kontadakis, G. Polyzoulis and G. Mbazios. Scientists are welcome to have access to the biological material at will and by appointment.

\footnotetext{
Authors' contributions

TM conceived the idea of the study, collected sea-bottom material by diving, searched for mollusks, participated in the identification of the species, processed the images and participated in the study's design and coordination and helped to draft the manuscript. CK collected sea-bottom material by diving, searched for mollusks, participated in the identification of the species, processed the images and participated in the study's design and coordination. GP collected sea-bottom material by diving, searched for mollusks, participated in the identification of the species, processed the images and participated in the study's design and coordination. GM collected sea-bottom
} 
material by diving, searched for mollusks, participated in the identification of the species, processed the images and participated in the study's design and coordination. SG-M collected biogenic sea-bottom material, searched for mollusks, participated in the identification of the species, designed figures and participated in the study's design and coordination and helped to draft the manuscript, supported with the bibliography sources and is the corresponding author. All authors read and approved the final manuscript.

\section{Author details}

${ }^{1}$ PO Box 48 K, 57500 Epanomi, Greece. ${ }^{2}$ Aristotelous 24, Hellinicon, 16777 Athens, Greece. ${ }^{3}$ PO Box 891, 57001 N. Redestos, Greece. ${ }^{4}$ Orfanidou 27, 11142 Athens, Greece. ${ }^{5}$ Department of Civil Engineering, School of Technological Applications, Alexander Technological Educational Institute of Thessaloniki (A.T.E.I.Th.), PO Box 141, 57400 Thessaloniki, Greece.

\section{Acknowledgements}

The authors are grateful to the three anonymous referees for their useful contribution to improve the publication. We are also grateful to the colleague Panagiotis Ovalis for his kind permission to add his Monophorus amicitiae specimens and data in this work.

\section{Competing interests}

The authors declare that they have no competing interests.

Ethics approval and consent to participate

Not applicable.

\section{Publisher's Note}

Springer Nature remains neutral with regard to jurisdictional claims in published maps and institutional affiliations.

Received: 6 April 2017 Accepted: 9 March 2018

Published online: 20 March 2018

\section{References}

1. Bianchi CN, Morri C. Marine biodiversity of the Mediterranean Sea: situation, problems and prospects for future research. Marine Poll Bull. 2000;40:367-76.

2. Zenetos A, Gofas S, Morri C, Rosso A, Violanti D, García Raso JE, et al. Alien species in the Mediterranean Sea by 2012. A contribution to the application of European Union's Marine Strategy Framework Directive (MSFD). Part 2. Introduction trends and pathways. Medit Mar Sci. 2012;13:328-52

3. Bianchi CN, Morri C, Chiantore M, Montefalcone M, Parravicini V, Rovere A. Mediterranean Sea biodiversity between the legacy from the past and a future of change. In: Stambler N, editor. Life in the Mediterranean Sea: a look at habitat changes. New York: Nova Science Publishers; 2012. p. 1-60.

4. Galil BS. A sea under siege-alien species in the Mediterranean. Biol Invasions. 2000;2:177-86.

5. Galil BS, Zenetos A. A sea change. Exotics in the Eastern Mediterranean. In: Leppakoski E, Gollasch S, Olenin S, editors. Invasive aquatic species of Europe: distribution, impacts and management. Dordrecht: Kluwer Scientific Publications; 2002. p. 325-36.

6. Zenetos A, Gofas S, Russo G, Templado J. Atlas of exotic species in the Mediterranean, vol. 3. Monaco: CIESM Publishers; 2003.

7. Koulouri P, Dounas C, Arvanitidis C, Koutsoubas D, Eleftheriou A. Molluscan diversity along a Mediterranean soft bottom sublittoral ecotone. Sci Mar. 2006:70:573-83.

8. Abdulla A, Linden O. Maritime traffic effects on biodiversity in the Mediterranean Sea: review of impacts, priority areas and mitigation measures. In: Abdulla A, Linden O, editors. Maritime traffic effects on biodiversity and potential mitigation measures: a synthesis. Malaga: IUCN Centre for Mediterranean Cooperation; 2008. p. 160-8.

9. Galil BS, Occhipinti-Ambrogi A, Gollasch S. Biodiversity impacts of species introductions via marine vessels. In: Abdulla A, Linden O, editors. Maritime traffic effects on biodiversity in the Mediterranean Sea: review of impacts, priority areas and mitigation measures. Malaga: IUCN Centre for Mediterranean Cooperation; 2008. p. 117-57.

10. Mollo E, Gavagnin M, Carbone M, Castelluccio F, Pozone F, Roussis V, et al. Factors promoting marine invasions: a chemoecological approach. Proc Natl Acad Sci USA. 2008;105:4582-6.

11. Raitsos DE, Beaugrand G, Georgopoulos D, Zenetos A, PancucciPapadopoulou AM, Theocharis A, et al. Global climate change amplifies the entry of tropical species into the eastern Mediterranean Sea. Limnol Oceanogr. 2010;55:1478-84.

12. Tzomos T, Kitsos MS, Koutsoubas D, Koukouras A. Evolution of the entrance rate and of the spatio-temporal distribution of Lessepsian Mollusca in the Mediterranean Sea. J Biol Res Thessalon. 2012;17:81-96.

13. Skliris N, Sofianos SS, Gkanasos A, Axaopoulos P, Mantziafou A, Vervatis V. Long-term sea surface temperature variability in the Aegean Sea. Adv Oceanogr Limnol. 2011;2:125-39.

14. Sayin E, Eronat C, Uçkaç \$̧, Beşiktepe ŞT. Hydrography of the eastern part of the Aegean Sea during the Eastern Mediterranean Transient (EMT). J Mar Syst. 2011:88:502-15.

15. Tsiaras KP, Kourafalou VH, Raitsos DE, Triantafyllou G, Petihakis G, Korres G. Inter-annual productivity variability in the North Aegean Sea: influence of thermohaline circulation during the Eastern Mediterranean Transient. J Mar Syst. 2012:96-97:72-81.

16. Koutsoubas D, Koukouras A, Voultsiadou-Koukoura E. Prosobranch Mollusc fauna of the Aegean Sea: new information, checklist, distribution. Israel J Zool. 1997;43:19-54

17. Manousis T, Mpardakis G, Paraskevopoulos C, Galinou-Mitsoudi S. The Bivalvia Mollusca of Thessaloniki and Thermaikos Gulfs (North Aegean Sea, Greece) with emphasis on new species for Hellenic waters. J Biol Res Thessalon. 2010;14:161-79.

18. Manousis A. The sea shells of Greece. Thessaloniki: Kyriakidis Brothers; 2012

19. Manousis T, Mpardakis G, Zamora Silva A, Paraskevopoulos C, Manios D, Galinou-Mitsoudi S. New findings of Gastropods in the Hellenic seas with emphasis on their origin and distribution status. J Biol Res Thessalon. 2012;18:249-64.

20. Manousis T, Galinou-Mitsoudi S. New and uncommon Bivalvia Mollusca of Thermaikos Gulf (NW Aegean Sea). J Biol Res Thessalon. 2013;20:339-66.

21. Manousis T, Galinou-Mitsoudi S. New gastropod records for the Eastern Mediterranean Sea and one new alien (Emarginula decorata Deshayes, 1863) for the Mediterranean Sea from NW Aegean Sea, Greece. J Biol Res Thessalon. 2014;21:20.

22. Manousis T, Kontadakis C, Mbazios G, Polyzoulis G, Galinou-Mitsoudi S. Possible poecilogony due to discontinuous multifactorial inheritance in some Mediterranean species of Raphitoma (Mollusca, Conoidea, Raphitomidae). In: Sajal R, editor. Organismal and molecular malacology. InTech; 2017. https://doi.org/10.5772/67847. https://www.intechopen. com/books/organismal-and-molecular-malacology/possible-poecilogony-due-to-discontinuous-multifactorial-inheritance-in-some-mediterranean-species-o. Accessed 30 Sept 2017.

23. Mienis HK. Marine molluscs from the Eastern Mediterranean. 9 again a new Indo-Pacific migrant: Diodora funiculata. Spirula. 2002;327:73.

24. Rusmore-Villaume ML. Seashells of the Egyptian Red Sea: the illustrated handbook. Cairo: The American University in Cairo Press; 2008.

25. Bosch DT, Dance SP, Moolenbeek RG, Oliver PG. Seashells of Eastern Arabia. Dubai: Emirates Printing Press; 1995.

26. Bedulli D, Bassignani F, Bertelli A. Specie rare nel Censimento della Malacofauna Marina Italiana. Boll Malaco. 2003;39:1-6.

27. Repetto G, Orlando F, Arduino G. Conchiglie del Mediterraneo. Alba: Amici del Museo "Federico Eucebio"; 2005.

28. Hoffman L, van Heugten B, Lavaleye MSS. Gastropoda (Mollusca) from the Rockall and Hatton Banks, northeastern Atlantic Ocean. Part 2. Misc. Malacologica. 2011;4:85-118.

29. Scaperrotta M, Bartolini S, Bogi C. Stadi di Accrescimento dei Molluschi Marini del Mediterraneo/stages of growth of marine molluscs of the Mediterranean, vol. 8. Ancona: L'Informatore Piceno; 2016.

30. Warén A, Nakano T, Sellanes J. A new species of lothia (Gastropoda: Lepetidae) from Chilean methane seeps, with comments on the accompanying gastropod fauna. Nautilus. 2011;125:1-14. 
31. Gofas S, Salas C, Rueda JL, Canoura J, Farias C, Gil J. Mollusca from a species-rich deep-water Leptometra community in the Alboran Sea. Sci Mar. 2014;78:537-53.

32. Kasemi D, Ruci S, Beqiraj S. Data on Macrozoobenthos of the Radhima coast, Vlora Bay, Albania. Natura Montenegrina Podgorica. 2013;12:77385. http://natura.pmcg.co.me/NM12/NM12-3/Kasemi_et_al_NM12-5117.pdf. Accessed 31 Mar 2017.

33. Dantart L, Luoue A. Cocculiniformia and Lepetidae (Gastropoda: Archaeogastropoda) from Iberian waters. J Molluscan Stud. 1994;60:277-313.

34. Taxonomic Database on European Marine Mollusca CLEMAM, Muséum National d'Histoire Naturelle, Department of Systematics \& Evolution, Paris. http://www.somali.asso.fr/clemam/. Accessed 31 Mar 2017.

35. Gofas S, Moreno D, Salas C. Moluscos Marinos de Andalucía, vol. 1 Málaga: Universidad de Málaga; 2011.

36. Segers W, Swinnen F, De Prins R. Marine Mollusks of Madeira. Zwijndrecht: Snoeck Publications; 2009

37. Rolán E, Hernández Otero JM, Swinnen F, Gómez R, Pérez Sánchez JM. Moluscos y conchas marinas de Canarias. Solenogastrales, Caudofoveata, Polyplacophora, Gastropoda, Bivalvia, Cephalopoda y Scaphopoda. Hachenheim: ConchBooks; 2011

38. Geiger DL. Monograph of the little slit shells. Volume 1. Introduction Scissurellidae. p. 1-728. Volume 2. Anatomidae, Larocheidae, Depressizonidae, Sutilizonidae, Temnocinclidae. p. 729-1291. Santa Barbara museum of natural history monographs; 2012.

39. McLean JH. The archaeogastropod family Addisoniidae Dall, 1882: life habit and review of species. Veliger. 1985;28:99-108.

40. Roldán E, Luque AA. The ecology, biology and taxonomy of Addisonia excentrica (Tiberi, 1855) (Cocculiniformia: Addisoniidae) from southern Spain. J Molluscan Stud. 2010;76:201-10.

41. Warén A. New and little known "Skeneimorph" gastropods from the Mediterranean Sea and the adjacent Atlantic Ocean. Boll Malacol. 1992:27:149-248.

42. Sasaki T, Warén A, Kano Y, Okutani T, Fujikura K. Gastropods from recent hot vents and cold seeps: systematics, diversity and life strategies. In: Kiel S, editor. The vent and seep biota. Topics in geobiology, vol. 33. Dordrecht: Springer; 2010.

43. Gönülal O, Topaloğlu B. Deep sea in the sea of Marmara. In: Özsoy E, Özsoy E, Çağatay MN, Balkis N, Balkis N, Öztürk B, editors. The Sea of Marmara; Marine biodiversity, fisheries, conservation and governance. Istanbul: Turkish Marine Research Foundation (TUDAV); 2016. p. 684-96.

44. Cachia C, Mifsud C, Sammut PM. The Marine Mollusca of the Maltese Islands (part II: Neotaenioglossa). Leiden: Backhuys Publishers; 1996.

45. Palazzi S, Villari A. Molluschi e Brachiopodi delle grotte sottomarine de Taorminense. La Conchiglia. 2001;297:1-56.

46. Crocetta F, Spanu M. Molluscs associated with a Sardinian deep water population of Corallium rubrum (Linné, 1758). Medit Mar Sci. 2008:9:63-85.

47. Cossignani T, Ardovini R. Malacologia Mediterranea. Atlante delle conchiglie del Mediterraneo. Ancona: L'Informatore Piceno; 2011

48. Vilvens C, Héros V. New species and new records of Danilia (Gastropoda: Chilodontidae) from the Western Pacific. Novapex. 2005;6:53-64.

49. Herbert DG. A revision of the Chilodontidae (Gastropoda: Vetigastropoda: Seguenzioidea) of southern Africa and the south-western Indian Ocean. Afr Invertebr. 2012;53:381-502.

50. Ghisotti F, Steinmann E. Danilia tinei (Calcara, 1839). Schede Malacologiche del Mediterraneo - scheda; 1970:03/Ab/01:1-4.

51. Cachia C, Mifsud C, Sammut PM. The marine shelled Mollusca of the Maltese Islands (Part I: Archaeogastropoda). Malta: Grima Printing \& Publishing Industries; 1991.

52. Navarro JB, Capdevila M. Atlas Malacologic del Delta de L’Ebre. Brunet: Sant Carles de la Ràpita J; 2005.

53. Scaperrotta M, Bartolini S, Bogi C. Stadi di Accrescimento dei Molluschi Marini del Mediterraneo/Stages of Growth of Marine Molluscs of the Mediterranean, vol. 1. Ancona: L'Informatore Piceno; 2009.

54. Öztürk B, Doğan A, Bitlis B, Önen M. Ptenoglossa species (Mollusca: Gastropoda) distributed along the Turkish Coast of the Aegean Sea. Turk J Zool. 2008:32:201-11.

55. Mastrototaro F, D'Onghia G, Corriero G, Matarrese A, Maiorano P,

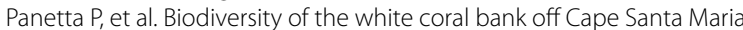

di Leuca (Mediterranean Sea): an update. Deep Sea Res Part 2 Top Stud Oceanogr. 2010;57:412-30.

56. Verduin A. Gibbula vimontiae, a good marine gastropod species from the Mediterranean. Basteria. 1979;43:27-31.

57. Cecalupo A, Buzzurro G, Mariani M. Contributo alla conoscenza della malacofauna del Golfo di Gabès (Tunisia). Milano: Quaderni della civica stazione idrobiologica di Milano; 2008.

58. Marine Biodiversity and Ecosystem Functioning EU Network of Excellence (MarBEF). http://www.marbef.org. Accessed 31 Mar 2017.

59. Scaperrotta M, Bartolini S, Bogi C. Stadi di Accrescimento dei Molluschi Marini del Mediterraneo/Stages of Growth of Marine Molluscs of the Mediterranean, vol. 2. Ancona: L'Informatore Piceno; 2010.

60. Evagelopoulos A, Poursanidis D, Papazisi E, Gerovasileiou V, Katsiaras N, Koutsoubas D. Records of alien marine species of Indo-Pacific origin at Sigri Bay (Lesvos Island, north-eastern Aegean Sea). Mar Biodivers Rec. 2015;8:e35. https://doi.org/10.1017/S1755267215000123.

61. Ellenic network on aquatic invasive species (ELNAIS). https://services. ath.hcmr.gr. Accessed 31 Mar 2017.

62. Rossini RA, Rueda JL, Tibbetts IR. Feeding ecology of the seagrassgrazing nerite Smaragdia souverbiana (Montrouzier, 1863) in subtropical seagrass beds of eastern Australia. J Molluscan Stud. 2014;80:139-47.

63. Streftaris N, Zenetos A. Alien Marine Species in the Mediterranean-the 100 'Worst Invasives' and their Impact. Medit Mar Sci. 2006;7:87-118.

64. Bouchet P, Warén A. Revision of the Northeast Atlantic bathyal and abyssal Mesogastropoda. Swedish Natural Science Reasearch Council. 1993;(Suppl):580-840.

65. Cecalupo A, Buzzurro G. Cerithiopsis annae: una nuova specie di Cerithiopsidae per le coste tunisine. Boll Malacol. 2004;40:132-5.

66. Baldovi JDO. Checklist of the marine testaceous gastropods in the southern part of Gulf of Valencia (Spain). Iberus. 2007;25:29-61.

67. Cecalupo A, Robba E. The identity of Murex tubercularis Montagu, 1803 and description of one new genus and two new species of Cerithiopsidae (Gastropoda: Triphoroidea). Boll Malacol. 2010;46:45-64.

68. Scaperrotta M, Bartolini S, Bogi C. Stadi di Accrescimento dei Molluschi Marini del Mediterraneo/Stages of Growth of Marine Molluscs of the Mediterranean, vol. 6. Ancona: L'Informatore Piceno; 2014.

69. Scuderi D, Criscione F. New ecological and taxonomical data on some Ptenoglossa (Mollusca, Caenogastropoda) from the Gulf of Catania (Ionian Sea). Biodivers J. 2011;2:35-48.

70. Romani L, Bartolini S. On the distribution of some Mediterranean Cerithiopsis Forbes et Hanley, 1850 (Caenogastropoda Cerithiopsidae). Biodivers J. 2014:5:367-70.

71. Prkić J, Buzzurro G. A new species of Cerithiopsis (Gastropoda Cerithiopsidae) from Croatian coasts. Triton. 2007:15:1-4

72. Prkić J, Mariottini P. Description of two new Cerithiopsis from the Croatian coast, with comments on the Cerithiopsis tubercularis complex (Gastropoda: Cerithiopsidae). Aldrovandia. 2009;5:3-27.

73. Delivering Alien Invasive Species Inventories for Europe (DAISIE). http:// www.europe-aliens.org/default.do. Accessed 31 Mar 2017.

74. Öztürk B, Recevik M, Geyran K. New alien Molluscs in the Mediterranean Sea. Cah Biol Mar. 2015:56:205-12.

75. Giannuzzi-Savelli R, Pusateri F, Palmeri A, Ebreo C. Atlante delle conchiglie marine del Mediterraneo, vol. 3. Roma: Evolver; 1999.

76. Aslan-Cihangir $\mathrm{H}$, Ovalis P. Seasonal variations and structure of the Molluscan assemblage in the Canakkale Strait (Turkey). Acta Zool Bulg. 2013;65:233-50

77. Peñas A, Rolán E, Luque ÁA, Templado J, Moreno D, Rubio F, et al. Marine mollusca from the Alboran Islands. Iberus. 2006;24:23-151.

78. Chirli C. Malacofauna Pliocenica Toscana, Vol. 7. Ptenoglossa: Cerithiopsidae, Triforidae, Epitoniidae, Eulimidae. Harxheim: ConchBooks; 2009.

79. Oliver JD, Templado J, Kersting D-K. Marine gastropods of the Columbretes Islands (Western Mediterranean). Iberus. 2012;30:49-87.

80. Jay M, Drivas J. The Cerithiopsidae (Gastropoda) of Reunion Island (Indian Ocean). Novapex. 2002;3:1-45.

81. Marshall BA. Cerithiopsidae (Mollusca: Gastropoda) of New Zealand, and a provisional classification of the family. New Zeal J Zool. 1978;5:47-120

82. Oliver JD, Calvo M, Guallart J, Sánchez-Tocino L, Templado J. Marine gastropods of the Chafarinas Islands (Southern Mediterranean). Iberus. 2015;33:97-150. 
83. Romani L. A new Mediterranean Monophorus species (Gastropoda: Triphoridae). Boll Malacol. 2015;51:3-8.

84. Trono D. Prima segnalazione di Monophorus amicitiae Romani, 2015 (Gastropoda: Triphoridae) e Fusinus corallinus Russo \& Germanà, 2014 (Gastropoda: Fasciolariidae) per il Salento. Thalassia Sal. 2016;38:143-7.

85. Bouchet P. Les Triphoridae de Méditerranée et du proche Atlantique (Mollusca, Gastropoda). Lav Soc Ital Malacol. 1985;21:5-58.

86. Bouchet $\mathrm{P}$, Waren A. Revision of the northeast Atlantic bathyal and abyssal Aclididae, Eulimidae, Epitoniidae (Mollusca, Gastropoda). Boll Malacol. 1986;1:299-576.

87. Taviani M. On the systematic position of Cerithiopsis concinna Sykes, 1925 with description of the new genus Narrimania (Gastropoda: Epitoniidae). Boll Malacol. 1983;19:237-44.

88. Mifsud C. Opaliopsis atlantis (Clench \& Turner, 1952) (Gastropoda: Epitoniidae) found on an actiniarian in the Mediterranean Sea. Boll Malacol. 2009;45:1-3.

89. Engl W. New records of molluscs for the Canary Islands. Novapex. 2009;10:165-72

90. Andrade BG, Costa PMS, Pimenta AD. Taxonomic review of the genus Opaliopsis (Gastropoda: Nystiellidae) from Brazil, with description of a new species. J Mar Biol Assoc UK. 2011;91:1561-6.

91. Delongueville C, Scaillet R. Curveulima dautzenbergi (Pallary, 1900) en Bretagne (France). Extension de l'aire de distribution. Xenophora. 2013;142:22-6.

92. Scaperrotta M, Bartolini S, Bogi C. Stadi di Accrescimento dei Molluschi Marini del Mediterraneo/Stages of Growth of Marine Molluscs of the Mediterranean, vol. 3. Ancona: L'Informatore Piceno; 2011.

93. Nekhaev IO. Distributional notes on Gibbula cineraria (Linnaeus, 1758), Pseudosetia turgida (Jeffreys, 1870) and Haliella stenostoma (Jeffreys, 1858) in Russian part of the Barents Sea (Gastropoda). Ruthenica. 2013:23:35-9

94. Rodriguez M, Pérez-Dionis G, Barquin J. Eulimid gastropods (Caenogastropoda: Eulimidae) of the Canary Islands. Part II. Species parasiting the crinoid Antedon bifida. Iberus. 2001;19:25-35.

95. Bieler R. Architectonicidae of the Indo-Pacific (Mollusca, Gastropoda). Stuttgart: Gustav Fischer Verlag Publishers; 1993. p. 1993.
96. Stanic R, Schiaparelli S. New findings of living specimens of the rare architectonicid Heliacus (Gyriscus) jeffreysianus (Tiberi, 1867). Boll Malacol. 2007:43:143-6.

97. Mifsud C, Ovalis P. Re-discovery of living specimens of Heliacus (Gyriscus) jeffreysianus (Tiberi, 1867) (Gastropoda: Architectonicidae). Iberus. 2008;26:1-4.

98. Smriglio C, Mariottini P, Gravina F. New data on Spirolaxis clenchi Jaume \& Borro, 1946, from the Mediterranean Sea (Gastropoda Prosobranchia: Architectonicidae). Basteria. 1990;54:211-6.

99. Warén A. A generic revision of the family Eulimidae (Gastropoda, Prosobranchia). J Mollus Stud. 1983;13:1-96.

100. Solsona M, Martinell J. Distribution of Architectonicidae (Heterobranchia, Gastropoda) of the Western Mediterranean Pliocene: Ecological and historical considerations. Palaeogeogr Palaeoclimatol Palaeoecol. 1996;126:281-90.

101. Verduin A. On the systematics of recent Rissoa of the subgenus Turboella Gray, 1847, from the Mediterranean and the European Atlantic coasts. Basteria. 1976;40:21-73.

102. Doneddu M, Trainito E. Conchiglie del Mediterraneo: Guida ai molluschi conchigliati. Castello: Trezzano sul Naviglio; 2005.

103. Zenetos A, Vassilopoulou V, Salomidi M, Poursanidis D. Additions to the marine alien fauna of Greek waters (2007 update). Mar Biodiv Records. 2008;1:e91. https://doi.org/10.1017/S1755267207009281.

104. World Register of Marine Species (WoRMS). http://www.marinespecies. org. Accessed 31 Mar 2017.

105. Marine Mediterranean Invasive Alien Species Database (MAMIAS) http://www.mamias.org. Accessed 31 Mar 2017.

106. Koukouras A. Check-list of marine species from Greece. Aristotle University of Thessaloniki. Assembled in the framework of the EU FP7 PESI project; http://www.marinespecies.org/aphia.php?p=sourcedetail s\&id=142068. Accessed 31 Mar 2017.

107. Todd JA. NMiTA (Neogene Marine Biota of Tropical America): introduction to molluscan life habits databases. http://nmita.iowa.uiowa.edu/ database/mollusc/mollusclifestyles.htm. Accessed 31 Mar 2017.

\section{Submit your next manuscript to BioMed Central and we will help you at every step:}

- We accept pre-submission inquiries

- Our selector tool helps you to find the most relevant journal

- We provide round the clock customer support

- Convenient online submission

- Thorough peer review

- Inclusion in PubMed and all major indexing services

- Maximum visibility for your research

Submit your manuscript at www.biomedcentral.com/submit
() Biomed Central 